\title{
Land Use/ Land Cover Dynamics Study and Prediction In Jaipur City using CA Markov Model Integrated with Road Network
}

Nitesh Kumar Mourya ( $\square$ princeofmouryaempire@gmail.com )

School Coordinator at Govt. Sin. Sec. School, Kukas, Compucom Institute of Information Technology and Management https://orcid.org/0000-0001-6391-9936

\section{Sana Rafi}

Jamia Millia Islamia Faculty of Natural Sciences

\section{Saima Shamoo}

Student, Swastik Edustart Geospatial School of Geoinformatics, New Deli, India

\section{Research Article}

Keywords: LULC, CA Markov, Jaipur city, prediction

Posted Date: August 17th, 2021

DOI: https://doi.org/10.21203/rs.3.rs-755200/v1

License: (a) (i) This work is licensed under a Creative Commons Attribution 4.0 International License. Read Full License 


\section{Abstract}

Land Use Land Cover (LULC) dynamics analysis is critical and should be done regularly. It draws attention to LULC developments that can be addressed before they become unmanageable disasters or circumstances. For the years 2000, 2010, and 2020, LULC change analysis was carried out in Jaipur City, Rajasthan, India. The LULC maps were created using Landsat data through a visual interpretation technique at a scale of 1:50,000. These maps were classified into vegetation, agriculture, built-up areas, barren land, and water bodies. LULC was predicted by extrapolating the current LULC change pattern. Using a Cellular Automata-Markov Chain Model (CA Markov) integrated with road network, the current LULC change trend was extrapolated and utilized to estimate the LULC map for the years 2020, 2030, 2040 , and 2050. The strategy was validated by estimating LULC change for 2020 and comparing it to the actual LULC map for that year. The urban area contributed to $4.75 \%$ in 2000 of the total area in Jaipur city. The percentage of area under urban class has increased to $9.68 \%$ in 2010 and $12.96 \%$ in 2020 . The prediction based on 2000-2010 and 2010-2020 has shown an unprecedented decadal growth in the builtup area till 2050. The prediction based on the 2000-2010 period has shown a rise of $92.04 \%$ during 2020$2030,77.13 \%$ during $2030-2040$ and, $64.34 \%$ during 2040-2050. The prediction based on the 2010-2020 period has shown a rise of $102.42 \%$ during $2020-2030,73.56 \%$ during $2030-2040$ and, $54.47 \%$ during 2040-2050. This study is, therefore, calls for policy interventions to manage population and urban growth.

\section{Introduction}

Land use land cover classification (LULCC) is a warning system that alerts people to actions that damage the environment while simultaneously highlighting the benefits of environmental conservation efforts like afforestation. LULCC analysis can detect the activities of humans and nature. Rapid urbanization is becoming an important development issue, especially in developing nations like India. $80 \%$ of the population lived in rural areas 30 years before but now the projections revealed that the world's urban population will double in the next 30 years, of which $70 \%$ of people will live in cities of developing countries. People are attracted to metropolitan facilities due to human psychology and social status influences. The urbanization trend in India is consistent with the global trend where 377 million people out of a total of 1210 million people live in 7935 towns across the country contributing to $31.2 \%$ of the total population (census, 2011). The country's urban population experienced rapid growth during the 1950s and 1960s and decrease during 1981-1991 and 1991-2001 but saw an absolute increase in 2011 when the level of urbanization increased from $27.7 \%$ in 2001 to $31.1 \%$ in 2011 with an increase of $3.3 \%$ during 2001-2011 compared to $2.1 \%$ during 1991-2001. India's urban population is characterized by a rapid rate of natural growth and immigration. And this pattern of urbanization has found a new dimension with the growth of industrialization and trade and transport development (Arafat, 2019). According to (Horo \& Punia, 2018), "urban spatial areas have expanded at an accelerated speed during the last few decades, and rates of urban population growth are higher than the overall growth in most cities because urban areas are the locus of economic activity and transportation nodes. These patterns of urban densification and internal modifications are of major concern to sustainable development because they represent the 
physical manifestations of a range of social, economic, cultural, and political dimensions associated with urban dynamics".

There are environmental, social, and economic threats as the cities expand at such an accelerated rate. According to (Singh, 1996), an additional need for food, clothing, housing, transport, sanitation, and healthcare, etc. increases because hundreds of thousands of people are being added annually to the city population. This is further elaborated by (Rahman, 1998), as per his study nearly 1.7 million people migrate from rural areas to the cities every year in search of employment and other related economic activities putting acute strains on urban resources finally leading to environmental degradation. Urbanization is, therefore, a concern for authorities to sustain and maintain urban facilities and services. Cities contribute greatly to Gross Domestic Product (GDP) so their involvement in maintaining the economic growth as well as sustaining them as a GDPs contributor is essential because expectations lie in the fact that cities will generate options for a common man to pursue livelihood and interests meaningfully. After all, they generally migrate to cities for employment. It is for this purpose, that urban growth should be monitored regularly, to detect changes and to predict future changes. So that, timely action could be taken to manage the populace and related issues. This task has been accomplished by researchers across the world as discussed in section 1.1. The present study is also an attempt to analyzed LULCC for the urban part of Jaipur and predicting the trend of changes for the future. The study of LULC dynamics extracts natural and anthropogenic negative and positive changes. It aids in the prioritization of management and conservation efforts.

The aims of this study are as follows:

- LULCC map preparation for 2000, 2010, and 2020 for urban Jaipur.

- LULC change analysis for the above-mentioned years (2 decades)

- Prediction of LULC maps for years 2030, 2040, and 2050.

The paper is organized into several sections. Section 1 presents an introduction and related studies on LULC dynamics and urban growth prediction. Section 2. deals with the study area, and data acquisition and processing are explained in section 3. The methodology is explained in section 4 and the results of the study are presented in section 5 . The findings and discussion, suggestions, and a conclusion are given in sections 6,7, and 8 respectively.

\subsection{Relevant studies}

(Clarke \& Gaydos, 1998) did urban growth prediction of San Francisco and Washington, Baltimore. They used satellite data and employed the Loose-Coupling automation model for the study that is based on Scale-independent traditional cellular automation. The urban growth was predicated for the years 2020, $2040,2060,2080$, and 2100. A similar attempt has been made by (Narimah Samat, 2009) to study urban spatial growth of the Seberang Perai region of Penang State, Malaysia using the CA Markov model. The prediction was done based on commercial parameters through the visual map interpretation. The researcher also focused upon the flood-prone zones in the study area. 
In another study, (Gupta, 2011) monitored the urban growth of Jaipur City, India from 1975 to 2009 using satellite data. The urban growth was also monitored from 1727 to 2001 using historical maps. The population increase was analyzed through census data for the predicted years. In the year 1975 , the builtup area covered an area of $1002.41 \mathrm{ha}^{2}$ that increased to $1221.98 \mathrm{ha}^{2}$ in 1986, $1268.12 \mathrm{ha}^{2}$ in 1991, and $2367.42 \mathrm{ha}^{2}$ in 2003 . The total urban growth was found to be $20.91 \mathrm{~km}^{2}$ in 2009 . The work is highly valuable as it accounted for urban growth in Jaipur city from 1727 to 2009, and since 2009 it is rapidly growing. So this work provided a basis for further research. (Triantakonstantis \& Mountrakis, 2012) did a review-based study that presented available urban growth prediction models. The identified models were Spatial Autocorrelation and Heterogeneity model, with underlying modeling algorithms including Artificial Neural Networks Modeling, Cellular Automata Modeling, Fractal Modeling, Linear/Logistic Regression, Agent-Based Modeling, and Decision Trees Modeling. It was found that among all models, Cellular Automata was a widely adopted model. It was evident by the fact, that $83 \%$ of the researchers used Cellular Automata, Logistics Regression used by $23 \%$, Artificial Neural Networks Modeling (12\%), Fractal Modeling (10\%), Agent-Based Modeling (9\%), and Decision Trees Modeling by only $2 \%$ of users.

(Aithal et al., 2013) analyzed urbanization in Grater Bangalore, India using Simulation modeling. Landsat 7 ETM + data for the years 2008, 2010, and 2012 downloaded from USGS, toposheets from Survey of India, Google Earth images, data from Bhuvan portal were utilized for the modeling. The urban growth analysis and its prediction were achieved by applying CA Markov Model. The researchers estimated the built-up area to be $97531.11 \mathrm{~km}^{2}$ in 2012 from the classified image, and on prediction, they found the area to be $142381,81 \mathrm{~km}^{2}$ under the built-up class. This showed a difference of $3 \%$ in the actual and predicted built-up area in 2012. Therefore, the prediction was reliable. In another work, Mahesh Kumar Jat et. al 2017 employed the SLEUTH Model incorporating Urban Growth Model (UGM), and Land Cover Deltatron (LCD) models to predict the urban growth of Ajmer city. Toposheets from Survey of India and GeoEye satellite data of the year 2015 were operated through ERDAS Imagine and AutoCAD software. They acquired the accuracy from 79\% (0.78) to 80\% (0.79) for the classified data in 2002 and 2015, based on those, growth was predicated for different years up to 2040 . According to the study, there was a $90 \%, 80 \%$, and $70 \%$ probability that the city growth of Ajmer takes place along the Jaipur Road (NH8), Foy Sagar, and Ana Sagar Lake. However, the areal extent, that too in which direction was not explained. The estimation of future area extent would otherwise be helped in the development of the studied area. (Dadras et al., 2015) predicted the urban growth from 1956 to 2012 in Bandar Abbas City, Iran using the Spatio-temporal analysis method. Landsat ETM + and GeoEye-1 satellite data, and aerial photographs were used. DEM layer was prepared through orthophotographs and aerial photos were utilized for construction, detection, and recognition. The analysis was performed in the ENVI 5.1, ERDAS Imagine 2010, Leica Photogrammetry, and ESRI ArcGIS 10.3 Version software. An increase in urban areas and a rising growth rate were observed. The highest growth was seen from 2001 to 2012, that was 1124.54 degrees of deviation (dd) and the lowest $74.49 \mathrm{dd}$ was observed from 1987 to 2001 . The urban area has increased from 242.83 dd in 1956 to $135.17 \mathrm{dd}$ in 1975 , and then to $102.45 \mathrm{dd}$ in 1987 . This study was not much reliable and accurate as the results were presented in degrees and the data used were aerial images and orthophotos. The simulation of the urban expansion was also attempted by (Jafari et al., 2016) in Gilan, Iran through the CA Markov model. Landsat 5 TM, Landsat 7 ETM +, and Landsat 8 OLI 
satellite data were used in this research work. The study revealed that the Gilan city would engross 71265 ha under built-up class contributing to $5.1 \%$ of the total land in 2025 and 78075 ha contributing to $5.6 \%$ of the total land area in 2037. An increase of $0.1 \%$ in the built-up area from 2013 to 2025 and $0.5 \%$ from 2025 to 2037 was observed in Gilan, Iran. (Mondal et al., 2016) studied the urban growth through LULC in Guwahati, the capital city of Assam, India. They used Landsat 5 TM, IRS-1C LISS-III, IRS-P6 (Resourcesat1) LISS-III 110/53 satellite data. LULC for the years 1987, 1997, and 2007 were generated. The LULC for the year 2007 was predicted and also validated through Kno statistics $(0.8347), \mathrm{K}$ location statistics (0.7928), and K location statistics Strata (0.8591).

(Maurya et al., 2016) analyzed the Urban Sprawl in Jaipur city. Landsat MSS, TM, and ETM + for the years 1981, 1991, 2001, and 2011 were used along with the Toposheets from India Geological Survey. They found that the built-up (urban) had covered an area of $317 \mathrm{~km}^{2}$ in 2011 , and as per the prediction, the area would likely increase to $500 \mathrm{~km}^{2}$ in 2021 . They used multilayer perceptron data to predict future city boundaries. So, therefore their study did not account for the area calculation under different LULC categories. (Kusuma \& Pradesh, 2017) simulated urban growth in Vijayawada, Andhra Pradesh using the CA Markov model in TerrSet Software. Landsat 5 TM for 1995 and 2005 and Landsat 8 OLI for 2015 were utilized. The findings showed that the city would grow to $13330.1 \mathrm{~km}^{2}$ with $9936 \mathrm{~km}^{2}$ under built-up class in 2025 and further increased to $13958.3 \mathrm{~km}^{2}$ with $628.2 \mathrm{~km}^{2}$ built-up area in 2045. (Mosammam et al., 2017) measured urban sprawl in Qom City, Iran on a spatial basis. They used Landsat 5 TM and Landsat 8 OLI satellite data for the years 1987, 1999, and 2013. They used ENVI 5.1 for atmospheric correction and Idrisi Selva for image classification and prediction. The built-up area of the city was found to be $10163.79 \mathrm{ha}^{2}$ in 2013, which would be increased to $11277.36 \mathrm{ha}^{2}$ in 2022 contributing to an increase of 3\%. (Lal et al., 2017) calculated urban growth patterns in Dhanbad Urban Agglomeration (DUA) with geoinformatics techniques. They used Landsat MSS for 1972, ETM+ for 1999 and 2011. The built-up area was $17,000,000 \mathrm{~m}^{2}$ in $1972,23,000,000 \mathrm{~m}^{2}$ in 1999 and $46,000,000 \mathrm{~m}^{2}$ in 2011 . The increase in the builtup area was consistent with the population density that was 26,828 Persons $/ \mathrm{km}^{2}$ in $1972,45,463$ Persons $/ \mathrm{km}^{2}$ in 1999 , and 25,785 Persons $/ \mathrm{km}^{2}$ in 2011. Therefore, the urban area has been increased by $5.6 \%$ in 1999 and $6.66 \%$ in 2011.

The prediction of urban growth using neural network coupled agents-based Cellular Automata model for Chennai Tamil Nadu, India was undertaken by (Aarthi \& Gnanappazham, 2018). They used Landsat satellite data for the years 2009, 2013, and 2016 to map the urban areas, and road network data was obtained from google earth, DEM from SRTM, categories of industry were acquired from the Government of India MEPZ. They validated LULC with the help of google earth. The total area of built-up would be $157.46 \mathrm{~km}^{2}$ in 2020. They presented results in terms of entropy value. (Siddiqui et al., 2018) studied urban growth dynamics using CA Markov and Logistic Regression of Lucknow city, India. They used Landsat 5 $\mathrm{TM}$, Landsat $7 \mathrm{ETM}+$, and Landsat $8 \mathrm{OLI}$ images. Additional data including the master plan from Lucknow Development Authority (LDA), DEM data from Bhuvan portal, road network and socio-economic factors from LDA, TCPO for 1993, 2003, and 2013, and population data 1991, 2001, and 2011 from Census of India were also utilized in this study. They found an increase of $48 \%$ in the built-up area covering $441 \mathrm{~km}^{2}$ in 2023. (Kar et al., 2018) monitored spatial-temporal dynamics of urban and peri-urban in central India. 
They utilized population data for the years 1951, 1961, 1971, 1981, 1991, 2001, and 2011 collected from the Census of India, toposheets from Survey of India, urban Development zone map from Nagpur Municipal Corporation (NMC) of 1991 and 2010, Handheld Global Positing System (GPS), Google Earth Images and satellite data of Landsat 5 TM. They categorized urban growth into three classes of settlement i.e high, medium, and low, and found $1771.8 \mathrm{~km}^{2}$ under high or dense settlement (3\%), 1712.3 $\mathrm{km}^{2}(3.4 \%)$ under medium, and $3261.1 \mathrm{~km}^{2}$ (6.5\%) under low class in the year 1991. In 2010, high class occupied $5036.3 \mathrm{~km}^{2}$ (10.1\%), medium $6532.4 \mathrm{~km}^{2}$ (13.1\%), and low $3289.4 \mathrm{~km}^{2}(6.6 \%)$. Therefore, an increase in built-up area was evident. (Bharath et al., 2018) studied the urban growth of rapidly urbanizing Indian cities namely Delhi, Mumbai, Pune, Coimbatore, Chennai in India. They used Landsat TM and ETM+ satellite data, Aster Dem data, Ground Control Points (GCPs) and Global Position System (GPS) data, Virtual spatial Maps, and Google Earth images. Population data from 1991 to 2011 from the Census of India was also used to study population dynamics in these cities. The results showed that urban growth would increase by $57 \%$ for the capital of India (Delhi), $27 \%$ for the economical capital of India (Mumbai), 45.8\% for Chennai, 50\% for Pune, and 37\% for Coimbatore) respectively by 2025. This prediction was based on the CA Markov model. (Achmad et al., 2018) done Urban Sustainability Planning of Banda Aceh, Indonesia through the CA Markov model. Landsat satellite images of 2005 and 2009 were used to predict urban growth for the year 2029. The ArcGIS Desktop 10.1, Idrisi Selva were used for unsupervised classification, analysis, and accuracy assessment. (Al-Darwish et al., 2018) studied the IBB city of Yemen using the CA Markov model, and the prediction was made for the years 2023 and 2033. They used Sanitation geographic data from (LCWS-IBB) and observed the increasing growth in the city from $28.41 \%$ in 2013 to $34.44 \%$ in 2023 , and a $43.11 \%$ increase in 2033 contributing to the total urban area rise of 2495.07 ha.

The urban growth in East China was simulated by (Liu et al., 2019) using the SLEUTH model. Landsat TM image data of 2000, 2005, 2010, and 2015 and DEM data acquired from USGS were used. FLAASH (Fast Line of Singh Atmospheric Analysis of Spectral Hypercubes) and ENVI 5.3 and RMS (root mean squared), Support vector machine (SVM) supervised classifier and ArcGIS 10.2 had been used for image preprocessing, classification, and prediction. According to their prediction for 2040, the built-up area would grow to $1434 \mathrm{~km}^{2}$ with a $3.12 \%$ growth rate and grassland with a $4.32 \%$ growth rate. The farmland area would decrease with a rate of 13.89\%. (Dhali et al., 2019) researched spatial-temporal growth of urban sub-center on 24 Parganas, Ganga River basin, India. This research was based on Landsat 5 TM, Landsat 7 ETM+, Landsat 8 OLI satellite data. They used data with higher accuracy for an instance, the accuracy and kappa accuracy was $91.12 \%$, and 0.93 for 2016 data. The Shannon entropy model was employed to calculate urban growth. Researchers found that the southern part of this area did not change because the large area was covered by river water. The study showed that the urban area of the city has increased by $38.46 \%$ from 2006 to 2016. A 22.25\% of Agriculture land was converted into a built-up area between 1989 and 2006 and a total of $26.21 \%$ agricultural land area was decreased. This study used Landsat 7 ETM+ that experienced Scan Line Corrector error. The demerit of using this data is, after correcting scan lines with several techniques, the size of the pixels is exaggerated. 
The urban growth prediction using socioeconomic latent parameters in the Pune district of Maharashtra was conducted by (Yadav et al., 2019). Researchers used Landsat 7 ETM + data from USGS with the correction of scan line error using the sliding windows method. LULC prediction was done using the CA Markov model. The LULC map and socioeconomic parameters were classified into Forest Canopy, Agriculture Area, Residential Area, Industrial Area, Common Open Area, Burnt Grass, Bright Soil, and Water Body. They used the integrated Land Change Modeler (LCM) of TerrSet software. The results obtained using HMM improve prediction accuracy by a large margin. For instance, an $11 \%$ increment in the precision of the persistence of Impervious Surface (I) was observed. Similarly, the precision of the Soil Vegetation (V) class type by a marginal $6 \%$. This is because the vegetation (S) class type has jumped up by $26 \%$. However, there is a drop in the precision of cover is an outcome of a relatively easy process as compared to $\mathrm{S}$ and $\mathrm{I}$.

(Mc Cutchan et al., 2020) did Semantic-based Urban Growth Predication. They used vector data (Point, Line, Polygon), categorized into classes (e.g., restaurant, street, supermarket, airport), being a part of a tree-structured OWL ontology, that was defined by the linked Geo Data and used raster data from 2012 to 2015. The results of this analysis were presented in cells within buffers of selected distances in meters and kilometers i.e $20 \mathrm{~m}, 50 \mathrm{~m}, 500 \mathrm{~m}, 1 \mathrm{~km}, 5 \mathrm{~km}, 10 \mathrm{~km}$, and $30 \mathrm{~km}$. They revealed that cell counts of 111,468 of the non-urban area were converted into an urban area within a distance of $20 \mathrm{~m}$. While cell counts of 32261 cells of the non-urban area were converted into an urban area within a distance of $50 \mathrm{~m}$. This study did not provide future trends and areal extent. Recently, (Ebrahimipour \& Farshchin, 2021) had predicted the growth of Bojnourd city of North Khorasan with the help CA Markov model. They used 1956, 1964, 1978, and 1994 Landsat satellite data and Quickbird Satellite data for the years 2004 and 2009. The urban growth has shown with the visual display of maps. However, they did not provide statistics of prediction. To conclude, the literature survey revealed that studies across the world have been conducted to monitor changes and to make predictions of urban growth from time to time. Many of the studies did not provide statistics of the area under different categories, such as (Clarke \& Gaydos, 1998; Ebrahimipour \& Farshchin, 2021; Narimah Samat, 2009).

\section{Study Area}

The city of Jaipur is the capital of India's area-wise largest state of Rajasthan. It is well known as the "pink city" across the globe. It is one of the most historical and top 10 largest cities of India. The Jaipur city was included in World Heritage Sites on 6 June 2019 by the UNESCO World Heritage Committee that inscribed seven cultural sites on UNESCO's World Heritage List. The city is also home to many of the worlds' heritage sites like Amer Fort and Jantar Mantar, so UNESCO awarded Jaipur city as a Heritage city on 5, February 2020 (Jagran Josh). The city was founded on 18 November 1727, by the Kacchawa Rajput ruler "Jai Singh II (Chisholm Hugh, 1911; Sen \& Nath 2007). He was the ruler of the Amer Empire. It was one of the earliest planned cities of modern India that was designed by Vidyadhar Bhattacharya (Government of Rajasthan, 2015). Jaipur is now a popular tourist destination of the world, and it along with Delhi and Agra form the west Golden Triangle tourist circuit of around $240 \mathrm{~km}(149 \mathrm{mi})$ length. 
This study is focused upon the urban area of Jaipur city as it has been growing rapidly. It has already been included in the Urban area as decided by Jaipur Development Authority and Jaipur municipal corporation. The area under study is located between $75.551^{\circ} \mathrm{E}$ to $76.035^{\circ} \mathrm{E}$ longitude and $26.681^{\circ} \mathrm{N}$ to $27.123^{\circ} \mathrm{N}$ latitude (Fig. 1), covering an area of $2328.33 \mathrm{~km}^{2}$.

<Fig. 1: a) Locational map of the study area and b) Satellite Image of the present time>

According to the (Census of India, 2011), Jaipur is the tenth most populated city in India. It has a populace of 34, 71,847 in 2011 (provisional reports of Census of India), which is now estimated to have increased to $4,007,505$ in 2021. In 1950, the population of Jaipur was only 294,021 and since 2015, it has grown to 98,172 representing an annual change of $2.5 \%$. The population for the year 2030 is estimated to be 4.9 million (UN World Urbanization Prospects) which was earlier estimated to be 3.9 million in 2020. As per Kappen's climate classification, Jaipur experience a monsoon-influenced hot semi-arid (BSh) climate. The average temperature of the city remains below or equals $20^{\circ} \mathrm{C}$ or $68^{\circ} \mathrm{F}$ between December and January. The highest temperature ever recorded was $48.5^{\circ} \mathrm{C}\left(119.3^{\circ} \mathrm{F}\right)$ in May while the lowest temperature ever recorded was $-2.2^{\circ} \mathrm{C}\left(28.0^{\circ} \mathrm{F}\right)$. The winter months are relatively dry with few rain spells obtained from the Mediterranean Sea Monsoon (known as Mahawat knows in Rajasthan). The highest average rainfall is measured in July, which is $214.0 \mathrm{~mm}$ and the lowest average rainfall $(30 \mathrm{~mm})$ is received in December (World Weather Information Service, 6 January 2021). Jaipur city is now emerging as an urban heat island zone like many other major cities of the world, but the surrounding rural region of the city has temperatures occasionally falling below freezing points in winters.

\section{Data Acquisition}

In this research work, the spatial-temporal data was collected in two steps. In the first steps, data was procured for land use land cover classification (LULC). The Satellite data, Landsat 5 TM for 2000, 2010, and Landsat 8 OLI for 2020 was downloaded from the United States Geological Survey (USGS) available at (https://earthexplorer.usgs.gov/). This data was then preprocessed for further analysis. The second step involves the collection of data for the LCM (Land Change Modular). Aster Global Digital Elevation Model was downloaded from Earth Data Search available at (https://search.earthdata.nasa.gov/search? $\mathrm{q}=$ aster). Road Network Map and Road Distance Map was obtained by (https://www.openstreetmap.org-/\#map=5/21.843/82.795) and the urban distance map was created by LULC of 2020. The details of the satellite images and additional data used in the present study are given in table 1 and Fig. 2 .

Table 1: Details of the satellite and additional data used in this study

<Fig. 2: Raw data used in the analysis>

3.1 Satellite Image Processing and Classification 
The data downloaded from USGS for LULC was processed in Erdas Imagine 2015 for Image preprocessing, classification, interpretation, and post-processing with False Colour Composite (FCC) of the satellite images. The maps were prepared at 1:50,000 scale. A hybrid (supervised and visual) classification scheme was adopted to prepare LULC maps. The categories of LULC classification were, vegetation, agriculture, settlements or built-up, barren land, and water bodies. Then the data was converted into integer format in ArcGIS Desktop 10.7 and again processed into Erdas Imagine 2015 for 8-bit unsigned thematic data (Fig. 2) for further processing in Idrisi Selva 17.0. The Additional data was prepared in ArcGIS 10.7 and QGIS 3.14 and was converted into integer 8 bit unsigned into Erdas Imagine.

In the present study, the Landsat 8 OLI data downloaded from USGS for the year 2020 has been utilized for land use land cover classification. The ring road (Fig. 1) in the study area was classified as a barren land feature in the automated classification and showed higher accuracy. To yield better results for the predictions, we have added ring road manually in the 2020 data and then classification was again done. The later classification has shown low accuracy as compared to the former classification. The accuracy assessment and Kappa statistics of the LULC data are presented in (Table 2).

Table 2: LULC data validation through; a) Accuracy assessment and, b) Kappa statics

\section{Method}

The prepared LULC and additional data were first imported into RST format into Idrisi Selva 17.0. Then LCM Modeler of IDISI Selva 17.0 was run to analyze change and to create change transition potential to predict LULC of the year 2020 based on 2000 and 2010 LULC data. The predicted map of 2020 was then validated with, i) the LULC 2020 prepared using satellite data, ii) LULC 2020, prepared by manually integrating road network. A deference of 1 percent was obtained. A similar process was employed again to predict future maps based on 2010 and 2020 LULC data. Change analysis for the years 2030, 2040, and 2050 was done. The entire methodology adopted in the present study is given in (Fig. 3). A more or less similar methodology had been used previously for Assam city by (Mondal et al., 2016). But, here we used different methods of raw data acquisition and of validating predicted data.

$<$ Fig. 3: Flow chart of the methodology adopted in this study>

\subsection{Change Detection and Future Prediction}

The change analysis was done using Matrix Union, a Summary report of Matrix of the LCM on Idrisi Selva 17.0. The change matrices were prepared from LULC classes during 2000-2010, and 2010-2020. For future prediction, the CA-MARKOV model (a part of LCM) of IDRISI Selva 17.0 was used for the prediction of LULC for the years 2020, 2030, 2040, and 2050 maps first based on (2000-2010) LULC data and then on 2010-2020 LULC data. Finally, the area of each class was calculated for each year i.e 2000, 2010, 2020, 2030, 2040, and 2050.

4.1.1 Land Change Modeler (LCM) 
Changes in land use land cover were analyzed with the help of LCM which is for ecological sustainability is an integrated software of IDRISI Selva and is also available in the Terra set software, developed by the Clark labs. The modeler calculates the land use land cover categories for earlier and later periods and finds out that a specific category of the earlier classification e.g vegetation is now converted into which category in the latter classification. Therefore, it predicts the land use and land cover based on the change analysis. The MARKOV Chain modeler is integrated with LCM here, to predict LULC based on land change trends and the transition potential.

\subsubsection{CA MARKOV MODEL}

Markov model does LULC simulation calculation of measuring LULC changes between $\mathrm{t} 1$ and $\mathrm{t} 2$ and extrapolating these changes into the future LULC (Eastman, 2009). CA-Markov Model is one of most of the common modeling methods that many researchers often using to prove the efficiency of the model for simulating urban growth (Jokar et al., 2013; White and Engelen, 1999). Because it is so reliable for further change prediction. The Markov model the state of a system with a random variable that changes through time (Gagniuc, 2017). Hierarchical Markov models can be applied to categorize human behavior at various levels of abstraction. For example, a series of simple observations, such as a person's location in a room, can be interpreted to determine more complex information, such as in what task or activity the person is performing. Two kinds of Hierarchical Markov Models are available which are the Hierarchical hidden Markov model (Fine and Singer, 1998), and the Abstract Hidden Markov Model (Bui et al., (2002). Equation (1) is the expansion of the calculation of the prediction of land-use changes by the Markov Model:

$$
S(t, t+1)=P i j \times S(t)
$$

where $S(t)$ is the system status at the time of $t, S(t+1)$ is the system status at the time of $t+1$; Pij is the transition probability matrix in a state which is calculated as follows (Sang et al., 2011)

$$
P=\left(P_{i j}\right)=\left|\begin{array}{ll}
P_{11} P_{12} & P_{1 n} \\
P_{21} P_{22} & P_{2 n} \\
P_{n 1} P_{n 2} & P_{n m}
\end{array}\right| \sum_{i=j}^{n} P_{i j}=1
$$

$$
(0 \leq \mathrm{Pij} \leq 1)
$$

$\mathrm{P}$ is the transition probability; Pij stands for the probability of converting from current state I to another state $\mathrm{j}$ in next time; PN is the state probability of any time. The low transition will have a probability near 0 and the high transition has a probability near 1 (Kumar et al., 2014). Markov Chain determines exactly how much land would be estimated to change from the present year to predicated year based on class change into $t 1$ to $t 2$ and it is also dependent on included transition sub-models. The transition probabilities file is the output in this process, which is a matrix that records the probability that each land 
cover class will change to every other class. Through the Markov chain modeling, the analysis of two different times LULC images induces the transition matrices, a transition area matrix, and a set of conditional probability images (Mishra et al., 2014). "The Markov chain model has consisted of two significant probabilities: Transition models may be particularly useful when factors causing landscape change (e.g., socio-economics) are difficult to represent mechanistically" (Turner, 1989).

\section{Results Of The Study}

In this study, the prediction of urban growth in Jaipur city was done by the Markov Chain model (illustrated in sec 4.1.2). The model calculates the future land-use change based on the change analysis, change trends, and potential transition among the various land use and land cover categories. Two different periods 2000-2010 and 2010-2020 were utilized for the prediction of urban growth in Jaipur for the years 2030, 2040 and, 2050. The result of change analyses and predictions are presented in the following sections.

The LULC change analysis for the period $2000-2010$ and $2010-2020$ is presented in table 3 . The analysis has shown that the vegetation-covered $1252.36 \mathrm{~km}^{2}$ in 2000 , and $485.37 \mathrm{~km}^{2}$ in 2010 , reflecting a decrease of $766.99 \mathrm{~km}^{2}$ during 2000-2010. The area under vegetation is further decreased to $306 \mathrm{~km}^{2}$ in 2020 reflecting a decrease of $179.15 \mathrm{~km}^{2}$ during 2010-2020. At first, an increase of $582.38 \mathrm{~km}^{2}$ has been observed for the barren class that has increased from $749.53 \mathrm{~km}^{2}$ in 2000 to $1331.91 \mathrm{~km}^{2}$ in 2010 . In the year 2020, the barren land has decreased to $791.05 \mathrm{~km}^{2}$ (table 3). The changes in vegetation and barren land are dependent upon seasons in Jaipur. The vegetation area tends to increase while barren land tends to decrease during the monsoon and this pattern reversed during the winter season. These changes have been monitored for many years by the corresponding author who was born and brought up in the study area. The area covered by water bodies has decreased from $2.37 \mathrm{~km}^{2}$ in 2000 to $1.33 \mathrm{~km}^{2}$ in 2010 , showing a decline of $1.03 \mathrm{~km}^{2}$ during 2000-2010 and it has increased to $13.52 \mathrm{~km}^{2}$ in 2020, showing an increase of $11.19 \mathrm{~km}^{2}$ during 2010-2020. This increase resulted from the enhanced Monsoonal rainfall and some government projects like Amanishah Nala (Dravyavati River).

The agriculture area has increased from $213.39 \mathrm{~km}^{2}$ in 2000 to $915.72 \mathrm{~km}^{2}$ in 2020 that contributed to an overall increase of $702.33 \mathrm{~km}^{2}$ during 2000-2020. In actuality, agriculture was found to be decreased when the image was validated through field check. This has resulted due to the mixing of vegetation and agriculture pixels because, on a satellite image, these two classes reflected the light in the same spectrum and thus classified as a single feature at many spots as shown in (Fig. 4). The built-up area has also increased from $110.68 \mathrm{~km}^{2}$ to $225.47 \mathrm{~km}^{2}$ during the period 2000-2010 that has again risen to 301.82 $\mathrm{km}^{2}$ in 2020 (table 3). This trend was also evident in the study conducted by (Gupta, 2011).In another study, (Maurya et al., 2016) found that Pink city has covered an area of $317 \mathrm{~km}^{2}$ in 2011, and as per the prediction this area would increase to $500 \mathrm{~km}^{2}$ in 2021.

Table 3 Change Matrix summary 2000-2010 and 2010-2020

Page 11/35 
$<$ Fig. 4: Vegetation and agricultural land reflecting the energy in the same spectrum leading to pixels mixing >

5.1 LULC Predication for 2020, 2030, 2040, and 2050 based on 2000-2010 and 2010-2020 LULC data

The LULC maps of 2000-2010 and 2010-2020 have been utilized to predict decadal maps for the years $2020,2030,2040$, and 2050. The statistics of these maps are summarized in table 4, the graph of percent change is shown in (Fig. 5) and the maps are presented in (Fig.6) and discussed in this section. Prediction based on 2000-2010 data has revealed that vegetation area would decline from $485.7 \mathrm{~km}^{2}$ in 2010 , to $453.28 \mathrm{~km}^{2}$ in $2020,433.50 \mathrm{~km}^{2}$ in $2030,416.86 \mathrm{~km}^{2}$ in 2040 , and $402.8 \mathrm{~km}^{2}$ in 2050 . This attributed to a total decrease of $82.9 \mathrm{~km}^{2}$ in 40 years. Agriculture would likely decrease from $284.25 \mathrm{~km}^{2}$ in 2010 to $244.86 \mathrm{~km}^{2}$ in 2050 , contributing a total decrease of $39.39 \mathrm{~km}^{2}$. Although, an increase in the barren land area has been observed from 2000 to 2010 (Table 3). But after 2010, a decrease in barren land is evident from $1331.91 \mathrm{~km}^{2}$ in 2010 to $1110.86 \mathrm{~km}^{2}$ in 2050 . The water bodies' area would decrease from $1.33 \mathrm{~km}^{2}$ to $1.05 \mathrm{~km}^{2}$ during the same period. Finally, the growth in built-up or settlement areas is observed. The built-up area would likely increase from $225.47 \mathrm{~km}^{2}$ in 2010 , to $335.25 \mathrm{~km}^{2}$ in 2020 , to $427.29 \mathrm{~km}^{2}$ in 2030 $\left(92.04 \mathrm{~km}^{2}\right), 505 \mathrm{~km}^{2}$ in $2040\left(77.14 \mathrm{~km}^{2}\right)$, and $568.76 \mathrm{~km}^{2}$ in $2050\left(64.34 \mathrm{~km}^{2}\right)$ as the results are given in (table 4 and figures $5 \mathrm{~A}$ and $6 \mathrm{~A}$ ).

The prediction based on 2010-2020, revealed that vegetation area would decrease from $306.22 \mathrm{~km}^{2}$ in 2020 to $296.69 \mathrm{~km}^{2}$ in $2030,285.09 \mathrm{~km}^{2}$ in $2040,275.64 \mathrm{~km}^{2}$ in 2050 . This attributed to a total decrease of $30.58 \mathrm{~km}^{2}$ in 30 years. Agricultural land would likely decrease from $915.72 \mathrm{~km}^{2}$ in 2020 , to $878.71 \mathrm{~km}^{2}$ in $2030,846.40 \mathrm{~km}^{2}$ in 2040 , and $820.31 \mathrm{~km}^{2}$ in 2050 contributing to a total decrease of $95.41 \mathrm{~km}^{2}$. Although, an increase in the barren land area has been observed from 2000 to 2010 (table 3). But after 2010, a decrease in barren land is evident from $1331.91 \mathrm{~km}^{2}$ in 2010 to $791.05 \mathrm{~km}^{2}$ in 2020 . The barren land would also decrease to 735.82 in $2030,706.67 \mathrm{~km}$ in 2040, and $688.10 \mathrm{~km}^{2}$ in 2050 . This attributed to a total decrease of $643.81 \mathrm{~km}^{2}$ in the barren land class. The water bodies' would decrease from 13.52 $\mathrm{km}^{2}$ in 2020 to $12.06 \mathrm{~km}^{2}$ in 2050. Finally, positive growth in built-up or settlement areas was observed. The built-up area would likely increase from $301.25 \mathrm{~km}^{2}$ in 2020 , to $404.24 \mathrm{~km}^{2}$ in 2030 (102.99 km²), $477.81 \mathrm{~km}^{2}$ in $2040\left(73.57 \mathrm{~km}^{2}\right)$, and to $532.27 \mathrm{~km}^{2}$ in $2050\left(54.46 \mathrm{~km}^{2}\right)$. Therefore, the urban area in Jaipur would increase by $231.02 \mathrm{~km}^{2}$ from 2020 to 2050 . It is concluded from the analysis, that the percentage increase was highest for built-up/settlement $\left(231.02 \mathrm{~km}^{2}\right.$ ) from 2020 to 2050, shown (table 4 and Figures 5B and 6B).

Table 4: Change Matrix summary 2020-2030, 2030-2040, and 2040-2050

<Fig. 5: Urban Growth prediction for the years 2020, 2030, and 2050 based on (5A) 2000-2010 LULC and (5B) 2010-2020 LULC>

<Fig. 6: Urban Growth prediction for the years 2020, 2030, 2040, and 2050 based on (6A) 2000-2010 LULC maps and (6B) 2010-2020 LULC maps > 
The difference in prediction, first based on (2000-2010 LULC data) and, then on (2010-2020 LULC data) arises mainly because of the two reasons which are discussed here. The LULC map of 2010 has been prepared using Landsat 5 satellite image while the LULC map of 2020 was prepared using Landsat 8 OLI image. The Landsat 5 has only one sensor namely TM sensor as compared to Landsat $8 \mathrm{OLI}$ that has two sensors OLI and TM. Thus, Landsat $8 \mathrm{OLI}$ produced high-quality data for classification comparative to Landsat $5 \mathrm{TM}$. So, the pixels values were not the same in both images utilized here for prediction. The second reason is that we have integrated a newly constructed road network manually in 2020 LULC data that enhanced the area under built-up/settlement class. So this might also be a probable reason for the differences in prediction.

\subsection{Accuracy Assessment of Predication (Validation)}

The validation of the 2020 LULC prediction was done with the help of a validation tool of the LCM modeler that produced a validation Image (Fig. 7). In this imagery, the red-colored portion represents the area where the software has not worked. While yellow-colored areas are those where class 1 is converted into class 4 and is showing in class $5(1|4| 5)$ and green colored areas are those where class 1 is converted into class 4 and shown in class 4 as represented by (1|4|4) in (Fig. 7). In this study class 1 repersents vegetation and Classes 2, 3, 4, 5 repesent agriculture, barren land, built-up and water bodies respectively.

<Fig. 7: Validation of predicated 2020 from LULC 2010 data by Idrisi Sleva 17.0>

The second method used for validation involves ArcGIS and MS excel 2019 for accurate assessment of LULC predication of 2020. In this analysis, the accuracy of urban prediction was 87.59 percent for simple 2020 LULC and 88.91 percent for LULC integrated with the road network. This is represented by different classes of LULC data (Fig. 8).

$<$ Fig. 8: Accuracy assessment of predicated 2020 LULC (A) Validation with 2020 LULC (A) Validation with 2020 LULC integrated with road network>

\section{Findings And Discussion}

The simulation of the Markov model indicated rapid urban growth in Jaipur city based on 2000-2010 as well as 2010-2020 LULC data. The overall growth of the city and comparison of urban growth prediction of Jaipur based on 2000-2010 and 2010-2020 LULC data is presented in Fig. 9. An overall increase of $233.51 \mathrm{~km}^{2}$ in a built-up area in 2050 is evident based on the 2000-2010 LULC data. In 2010, the built-up area accounted for $1331.91 \mathrm{~km}^{2}$. The built area has increased from $225.47 \mathrm{~km}^{2}$ to $317.51 \mathrm{~km}^{2}$ during 2020-2030, adding $92.04 \mathrm{~km}^{2}$. Their area was again increased from $317.51 \mathrm{~km}^{2}$ to $394.64 \mathrm{~km}^{2}$ during 2030-2040, adding $77.13 \mathrm{~km}^{2}$ and from $394.64 \mathrm{~km}^{2}$ to $458.98 \mathrm{~km}^{2}$ during 2040-2050, adding $64.34 \mathrm{~km}^{2}$. This accounted for the decadal growth rate of $77.22 \mathrm{~km}^{2}$. The prediction results based on 2020 data revealed that the built-up area in 2020 was $335.35 \mathrm{~km}^{2}$ that increased to $438.08 \mathrm{~km}^{2}$ during 2020-2030, adding $102.73 \mathrm{~km}^{2}$. This area was again increased from $438.08 \mathrm{~km}^{2}$ to $511.64 \mathrm{~km}^{2}$ during $2030-2040$, 
adding $73.56 \mathrm{~km}^{2}$ and from $511.64 \mathrm{~km}^{2}$ to $566.11 \mathrm{~km}^{2}$ during $2040-2050$, adding $54.47 \mathrm{~km}^{2}$. This accounted for the decadal growth rate of $76.92 \mathrm{~km}^{2}$. Therefore, an overall increase of 230.51 $\mathrm{km}^{2}$ in the built-up area in 2050 is evident based on the 2010-2020 LULC data. In a nutshell, the built-up area would increase by a mean of 232.135 [233.51(2010) to $230.76(2020)] \mathrm{km}^{2}$. This unprecedented growth of a built-up area is likely to be consistent with the rising population in the city as shown in (Fig. 10a and Fig.12b). The data on population was available at https://esa.un.org/unpd/wup/. There are environmental, social, and economic threats as the cities expand rapidly. This study validated that the built-up area of urban Jaipur would be doubled by 2050 being consistent with population growth.

<Fig. 9: Comparision of urban growth prediction of Jaipur based on 2000-2010 and 2010-2020 LULC data>

<Fig. 10 Population rise in Jaipur city; 12a) Population in absolute numbers, 12b) Population growth in numbers>

The migration from rural areas to the urban areas in search of employment and other related economic activities would engross acute strains on urban resources that would finally lead to environmental degradation in Jaipur city. It was also evident from ground-truthing that people from rural areas are now settling in the agricultural farmlands of Urban Jaipur because of the dual benefit of living and working on the same farmlands. This is leading to a decrease in the size of agricultural land or farmlands (Fig. 11). In the study area, it has been observed that the mentality of the majority of the populace is that the urban areas would bring prosperity to their life.

$<$ Fig. 11. Conversion of larger farmlands into smaller units due to human settlement $>$

According to (ARUP, 2015) accelerating urbanization also means that the concentration of people and assets in cities is rapidly rising, leading to increased exposure to hazards such as urban floods, extreme heat, increased environmental pollution. This creates opportunities for innovations to both reduce the risks from climate change and maximize any potential opportunities. The rapid urban growth would pressurize water resources. The groundwater is depleting day by day and it would become one of the biggest issues in near future, especially with the prevailing variability in climate. As the climate of the study area lies in a monsoon-influenced hot semi-arid (BSh) climate, therefore, the monsoonal rainfall occurs as few spells and is not capable of meeting the water requirement in the city. The government must address this issue now, to lower down the risk for the future population. It becomes more relevant as Jaipur is a Heritage City, the shortage of water would affect tourism, thereby the economy. As for now, local administration i.e Panchayati Raj is working on this issue by storing monsoon rainfall water through DAMs, but this initiative is not enough because of the shorter duration of the monsoon period of the region. Therefore, two suggestions are proposed for generating a permanent solution to this problem in the study region.

\section{Suggestions}


Two river links are suggested in Fig. 12 to fulfill the requirements of water in the city. In the map, blue lines are representing the existing river network whereas the red lines representing potential links that can be made to connect rivers. In this way, water from Chambal and Yamuna can be shifted to Ramgarh Dam. We choose the Ramghar dam for diverting water in the city and other places for agriculture, drinking, and other purposes. The dam is known to have provided water for drinking purposes in the whole of Jaipur city before 2005. The first link can be created from the Yamuna River. However, the river is highly polluted and loaded with organic and inorganic pollutants. The highest pollution is observed on the Wazirabad outlet where the Yamuna enters Delhi (Sharma, et al. 2015). As per a study done in 2016, the Yamuna River is so polluted, that there is $100 \%$ urban metabolism of River Yamuna as it passes through the National Capital Territory (NCT) of Delhi. So, the water cannot be directly used. For this purpose, the government can construct a water treatment plant after Delhi. Then, its water can be diverted to Rajasthan. The total length of the link to be constructed is 10.65 kilometers.

<Fig. 12: Proposal for water resource allocation >

The $2^{\text {nd }}$ suggestion is for constructing a DAM on Chambal and Banas doab. This can be easy to achieve as the Banas river is a seasonal river and an electric dam can be constructed. The total link length to be constructed is 17.14 kilometers. With the implementation of any one of the two suggested projects, the agriculture, and vegetation area would increase. The groundwater level also increases.

\section{Conclusions}

Cities contribute greatly to Gross Domestic Product (GDP) so their involvement in maintaining the economic growth as well as sustaining them as a GDPs contributor is essential because expectations lie in the fact that cities will generate options for a common man to pursue livelihood and interests meaningfully. After all, they generally migrate to cities for employment. The urban area contributed to 4 . $75 \%$ in 2000 of the total area in Jaipur city. The percentage of area under urban class has increased to $9.68 \%$ in 2010 and $12.96 \%$ in 2020. The prediction based on 2000-2010 and 2010-2020 has shown an unprecedented decadal growth in the built-up area till 2050. The prediction based on the 2000-2010 period has shown a rise of $92.04 \%$ during 2020-2030, $77.13 \%$ during $2030-2040$ and, $64.34 \%$ during $2040-$ 2050. The prediction based on the $2010-2020$ period has shown a rise of $102.42 \%$ during $2020-2030$, $73.56 \%$ during $2030-2040$ and, $54.47 \%$ during $2040-2050$. Urbanization is a concern for authorities to sustain and maintain urban facilities and services. There are environmental, social, and economic threats as the cities expand rapidly. This would engross acute strains on urban resources that would finally lead to environmental degradation in Jaipur city. This study is, therefore, calls for policy interventions to manage population and urban growth.

\section{Declarations}

Funding: Funding was not received from any organization and company for conducting the present study 
Conflict of interest The authors declare that they have no conflict of interest. All the authors have equally contributed to the present work.

Human and animal rights No human and/or animal participation was involved in the study.

Competing interests: The authors declare no competing interest.

\section{References}

Aarthi, A. D., \& Gnanappazham, L. (2018). Urban growth prediction using neural network coupled agentsbased Cellular Automata model for Sriperumbudur Taluk, Tamil Nadu, India. Egyptian Journal of Remote Sensing and Space Science, 21(3), 353-362. https://doi.org/10.1016/j.ejrs.2017.12.004

Achmad, A., Irwansyah, M., \& Ramli, I. (2018). Prediction of future urban growth using CA-Markov for urban sustainability planning of Banda Aceh, Indonesia. IOP Conference Series: Earth and Environmental Science, 126(1). https://doi.org/10.1088/1755-1315/126/1/012166

Aithal, B. H., Vinay, S., Durgappa, S., \& Ramachandra, T. V. (2013). Modeling and Simulation of Urbanisation in Greater Bangalore, India. National Spatial Data Infrastructure Conference, $1=7$.

Al-Darwish, Y., Ayad, H., Taha, D., \& Saadallah, D. (2018). Predicting the future urban growth and it's impacts on the surrounding environment using urban simulation models: Case study of Ibb city - Yemen. Alexandria Engineering Journal, 57(4), 2887-2895. https://doi.org/10.1016/j.aej.2017.10.009

Arafat, Y (2019). Urbanization in Asansol City and its Impact on Surrounding Areas. Environment and Social Development, Keystone Publishing House, Delhi, 122-137.

ARUP. (2015). City Climate Hazard Taxonomy. www.arup.com

Bharath, H. A., Chandan, M. C., Vinay, S., \& Ramachandra, T. V. (2018). Modelling urban dynamics in rapidly urbanising Indian cities. Egyptian Journal of Remote Sensing and Space Science, 21(3), 201-210. https://doi.org/10.1016/j.ejrs.2017.08.002

Bui, H. H., Venkatesh, S., \& West, G. (2002). Policy recognition in the abstract hidden markov model. Journal of Artificial Intelligence Research, 17, 451-499.

Chisholm, Hugh, ed. (1911). "Jaipur". Encyclopædia Britannica. 15 (11th ed.). Cambridge University Press. pp. 128-129.Textbook of Indian History and Culture. New Delhi: MACMILLAN

Clarke, K. C., \& Gaydos, L. J. (1998). Loose-coupling a cellular automaton model and GIS: Long-term urban growth prediction for San Francisco and Washington/Baltimore. International Journal of Geographical Information Science, 12(7), 699-714. https://doi.org/10.1080/136588198241617 
Dadras, M., Shafri, H. Z. M., Ahmad, N., Pradhan, B., \& Safarpour, S. (2015). Spatio-temporal analysis of urban growth from remote sensing data in Bandar Abbas city, Iran. Egyptian Journal of Remote Sensing and Space Science, 18(1), 35-52. https://doi.org/10.1016/j.ejrs.2015.03.005

de Noronha Vaz, E., Nijkamp, P., Painho, M., \& Caetano, M. (2012). A multi-scenario forecast of urban change: A study on urban growth in the Algarve. Landscape and Urban Planning, 104(2), 201-211.

Dhali, M. K., Chakraborty, M., \& Sahana, M. (2019). Assessing spatio-temporal growth of urban sub-centre using Shannon's entropy model and principle component analysis: A case from North 24 Parganas, lower Ganga River Basin, India. Egyptian Journal of Remote Sensing and Space Science, 22(1), 25-35. https://doi.org/10.1016/j.ejrs.2018.02.002

Eastman, J. R. 2009. IDRISI Taiga Guide to GIS and Image Processing. Worcester, MA: Clark Labs Clark University.

Ebrahimipour, A., \& Farshchin, A. (2021). Prediction of Urban Growth through Cellular Automata-Markov Chain Prediction of Urban Growth through Cellular Automata-Markov Chain Introduction. January 2016.

Fine, S.; Singer, Y. (1998). "The hierarchical hidden Markov model: Analysis and applications". Machine Learning. 32 (1): 41-62. doi:10.1023/A:1007469218079.

Gagniuc, P. A. (2017). Markov Chains From Theory to Implementation and Experimentation of Engineering in Foreign Languages. https://lccn.loc.gov/2017011637

Gupta, R. K. (2011). Change Detection Techniques for Monitoring Spatial Urban Growth of Jaipur City. Institute of Town Planners, India Journal, 8(3), 88-104.

Horo, J. P., \& Punia, M. (2019). Urban dynamics assessment of Ghaziabad as a suburb of National Capital Region, India. GeoJournal, 84(3), 623-639.

Jafari, M., Majedi, H., Monavari, S. M., Alesheikh, A. A., \& Zarkesh, M. K. (2016). Dynamic simulation of urban expansion through a CA-markov model case study: Hyrcanian region, Gilan, Iran. European Journal of Remote Sensing, 49, 513-529. https://doi.org/10.5721/EuJRS20164927

Jokar, J., Helbich, M., \& Noronha, E. De. (2013). Spatiotemporal simulation of urban growth patterns using agent-based modeling: The case of Tehran. CITIES, 32, 33-42.

https://doi.org/10.1016/j.cities.2013.01.005

Kar, R., Obi Reddy, G. P., Kumar, N., \& Singh, S. K. (2018). Monitoring spatio-temporal dynamics of urban and peri-urban landscape using remote sensing and GIS - A case study from Central India. Egyptian Journal of Remote Sensing and Space Science, 21(3), 401-411.

https://doi.org/10.1016/j.ejrs.2017.12.006 
Kumar, S., Radhakrishnan, N., \& Mathew, S. (2014). Land use change modelling using a Markov model and remote sensing. December, 37-41. https://doi.org/10.1080/19475705.2013.795502

Kusuma, S., \& Pradesh, A. (2017). Engineering URBAN GROWTH PREDICTION USING GEO- SIMULATION AND MODELING Kusuma . Sundara Kumar Pinnamaneni . Udaya Bhaskar Kollipara . Padma ABSTRACT. December 2016.

Lal, K., Kumar, D., \& Kumar, A. (2017). Spatio-temporal landscape modeling of urban growth patterns in Dhanbad Urban Agglomeration, India using geoinformatics techniques. Egyptian Journal of Remote Sensing and Space Science, 20(1), 91-102. https://doi.org/10.1016/j.ejrs.2017.01.003

Liu, Y., Li, L., Chen, L., Cheng, L., Zhou, X., Cui, Y., Li, H., \& Liu, W. (2019). Urban growth simulation in different scenarios using the SLEUTH model: A case study of Hefei, East China. PLoS ONE, 14(11), 1-22. https://doi.org/10.1371/journal.pone.0224998

Maurya, R. K., Saxena, M. R., \& Akhil, N. (2016). Intelligent Systems Technologies and Applications. Advances in Intelligent Systems and Computing, 384(January 2016), 247-257.

https://doi.org/10.1007/978-3-319-23036-8

Mc Cutchan, M., Özdal-Oktay, S., \& Giannopoulos, I. (2020). Semantic-based urban growth prediction. Transactions in GIS, 24(6), 1482-1503. https://doi.org/10.1111/tgis.12655

Mishra, V., Rai, P., \& Mohan, K. (2014). Prediction of land use changes based on land change modeler (LCM) using remote sensing: A case study of Muzaffarpur (Bihar), India. Journal of the Geographical Institute Jovan Cvijic, SASA, 64(1), 111-127. https://doi.org/10.2298/ijgi1401111m

Mondal, M. S., Sharma, N., Garg, P. K., \& Kappas, M. (2016). Statistical independence test and validation of CA Markov land use land cover (LULC) prediction results. Egyptian Journal of Remote Sensing and Space Science, 19(2), 259-272. https://doi.org/10.1016/j.ejrs.2016.08.001

Mosammam, H. M., Nia, J. T., Khani, H., Teymouri, A., \& Kazemi, M. (2017). Monitoring land use change and measuring urban sprawl based on its spatial forms: The case of Qom city. Egyptian Journal of Remote Sensing and Space Science, 20(1), 103-116. https://doi.org/10.1016/j.ejrs.2016.08.002

Narimah Samat. (2009). Integrating GIS and CA-MARKOV model in evaluating urban spatial growth. Malaysian Journal of Environmental Management, 10(1), 83-100. http://journalarticle.ukm.my/2281/1/Artikel_6_Narimah.pdf

Rahman, A. (1998). Housing Environment and Health, B.R Pub Corp. Delhi, India: ISBN 81-7646-000-1.

Sang, L., Zhang, C., Yang, J., Zhu, D., \& Yun, W. (2011). Simulation of land use spatial pattern of towns and villages based on CA-Markov model. Mathematical and Computer Modelling, 54(3-4), 938-943. https://doi.org/10.1016/j.mcm.2010.11.019 
Sen, Sailendra Nath (2007). Textbook of Indian History and Culture. New Delhi: MACMILLAN. p. 167. ISBN 978-1403-93200-6.

Sharma, M., \& Chaudhry, S. (2015). Impact of Industrial Pollution on Yamuna River: A Review. doi, 10, 512521.

Siddiqui, A., Siddiqui, A., Maithani, S., Jha, A. K., Kumar, P., \& Srivastav, S. K. (2018). Urban growth dynamics of an Indian metropolitan using CA Markov and Logistic Regression. Egyptian Journal of Remote Sensing and Space Science, 21(3), 229-236. https://doi.org/10.1016/j.ejrs.2017.11.006

Singh, G., Deb, M., \& Ghosh, C. (2016). Urban metabolism of river Yamuna in the National Capital Territory of Delhi, India. Int J Adv Res, 4, 1240-1248.

Singh, A. L., Fazal, S., Azam, F., \& Rahman, A. (1996). Income, environment and health: A household level study of Aligarh City, India. Habitat International, 20(1), 77-91.

Soryani, M. (2014). Amir Farid Aminian Modarres. Analysis and Applications, 32(1), 41-62.

Triantakonstantis, D., \& Mountrakis, G. (2012). Urban Growth Prediction: A Review of Computational Models and Human Perceptions. Journal of Geographic Information System, 04(06), 555-587. https://doi.org/10.4236/jgis.2012.46060

Turner, M. G. (1989). Landscape ecology: the effect of pattern on process. Annual Review of Ecology and Systematics. Vol. 20,171-197. https://doi.org/10.1146/annurev.es.20.110189.001131

Urban Metabolism of River Yamuna in the National Capital Territory of Delhi, India". ResearchGate. Retrieved 25 November 2020

Yadav, P., Ladha, S., Deshpande, S., \& Curry, E. (2019). Computational Model for Urban Growth Using Socioeconomic Latent Parameters. Lecture Notes in Computer Science (Including Subseries Lecture Notes in Artificial Intelligence and Lecture Notes in Bioinformatics), 11329 LNAl, 65-78.

https://doi.org/10.1007/978-3-030-13453-2_6

https://web.archive.org/web/20151103091000/http://jaipur.rajasthan.gov.in/content/raj/jaipur/en/aboutjaipur/history.html)

https://worldpopulationreview.com/world-cities/jaipur-population

https://worldweather.wmo.int/en/city.html?cityld=531

https://earthexplorer.usgs.gov/

https://search.earthdata.nasa.gov/search?q=aster

https://www.openstreetmap.org-/\#map=5/21.843/82.795 
https://en.unesco.org/news/seven-cultural-sites-inscribed-unescos-world-heritage-list

https://www.jagranjosh.com/current-affairs/jaipur-receives-unesco-world-heritage-city-certificate1580964894-

1\#: :text=Jaipur\%20as\%20World\%20Heritage\%20City,ceremony\%20held\%20at\%20Albert\%20Hall

http://censusindia.gov.in/2011-Common/CensusData2011.html

\section{Tables}

Table 1: Details of the satellite and additional data used in this study

\begin{tabular}{|c|c|c|c|c|c|}
\hline $\begin{array}{l}\text { S. } \\
\text { No. }\end{array}$ & Data Type & Source & $\begin{array}{l}\text { Acquiring Date } \\
\text { (yyyy.mm.dd.) }\end{array}$ & $\begin{array}{l}\text { Path \& } \\
\text { Raw }\end{array}$ & Resolution \\
\hline & Satellite data & & & & \\
\hline 1. & Landsat $05 \mathrm{TM}$ & USGS & 2000.04 .14 & 147 / 41 & $30 \mathrm{~m}$ \\
\hline 2. & Landsat $05 \mathrm{TM}$ & USGS & 2010.04 .10 & 147 / 41 & $30 \mathrm{~m}$ \\
\hline \multirow[t]{2}{*}{3.} & Landsat $08 \mathrm{OLI}$ & USGS & 2020.04 .21 & 147 / 41 & $30 \mathrm{~m}$ \\
\hline & Additional data & & & & \\
\hline 4. & $\begin{array}{l}\text { Road Network } \\
\text { Map }\end{array}$ & OSM Data & - & - & - \\
\hline 5. & Road Distance & OSM Data & - & - & - \\
\hline 6. & DEM & Aster Dem & - & - & $90 \mathrm{~m}$ \\
\hline 7. & Slope & Aster Dem & - & - & $90 \mathrm{~m}$ \\
\hline 8. & Urban Distance & $\begin{array}{l}\text { Based on LULC of } \\
2020\end{array}$ & 2020.04 .21 & - & $30 \mathrm{~m}$ \\
\hline
\end{tabular}

Table 2 LULC data validation through; a) Accuracy assessment and, b) Kappa statics

Table 2 a) Accuracy assessment 


\begin{tabular}{|lllll|}
\hline Classes & $\begin{array}{l}\mathbf{2 0 0 0} \\
\text { Produce/User }\end{array}$ & $\begin{array}{l}\mathbf{2 0 1 0} \\
\text { Produce/User }\end{array}$ & $\begin{array}{l}\mathbf{2 0 2 0} \\
\text { Produce/ User }\end{array}$ & $\begin{array}{l}\mathbf{2 0 2 0} \text { integrated with Ring Road } \\
\text { Produce/User }\end{array}$ \\
\hline Vegetation & $85.71 / 90.00$ & $95.00 / 95.00$ & $93.33 / 93.33$ & $100 / 85.00$ \\
\hline Agriculture & $100 / 95.00$ & $94.44 / 85.00$ & $88.89 / 100$ & $80.00 / 100$ \\
\hline Barren & $100 / 100$ & $90.48 / 95.00$ & $93.75 / 93.75$ & $84.21 / 80.00$ \\
\hline Settlement & $100.00 / 90.00$ & $100 / 100$ & $93.75 / 93.75$ & $94.74 / 90.00$ \\
Water & $100 / 100$ & $100 / 93.75$ & $100 / 93.75$ & $100 / 100$ \\
\hline Overall & $93.88 \%$ & $93.75 \%$ & $93.75 \%$ & $90.91 \%$ \\
\hline
\end{tabular}

Table 2 b) Kappa statics

\begin{tabular}{|lllll|}
\hline Classes & $\mathbf{2 0 0 0}$ & $\mathbf{2 0 1 0}$ & $\mathbf{2 0 2 0}$ & $\mathbf{2 0 2 0}$ integrated with Ring Road \\
\hline Vegetation & 0.8727 & 0.9368 & 0.8462 & 0.8189 \\
\hline Agriculture & 0.9380 & 0.8154 & 1.0000 & 1.0000 \\
\hline Barren & 0.9364 & 0.9360 & 0.9219 & 0.7525 \\
\hline Settlement & 1.0000 & 1.0000 & 0.9219 & 0.8763 \\
\hline Water & 0.8775 & 0.9259 & 0.9231 & 1.0000 \\
\hline Overall & 0.9236 & 0.9221 & 0.9219 & 0.8864 \\
\hline
\end{tabular}

Table 3 Change Matrix summary 2000-2010 and 2010-2020 


\begin{tabular}{|llllll|}
\hline Classes & $\begin{array}{l}\text { Year 2000 Area } \\
\text { in } \\
\text { Km² }\end{array}$ & $\begin{array}{l}\text { Year 2010 } \\
\text { Area in } \mathrm{Km}^{2}\end{array}$ & $\begin{array}{l}\text { 2000-2010 } \\
\text { Change } \\
(\%)\end{array}$ & $\begin{array}{l}\text { Year 2020 } \\
\text { Area in } \mathrm{Km}^{2}\end{array}$ & $\begin{array}{l}\text { 2010-2020 } \\
\text { Change (\%) }\end{array}$ \\
\hline Vegetation & $\begin{array}{l}1252.36 \\
(53.79 \%)\end{array}$ & $485.37(20.85 \%)$ & $-32.94 \%$ & $\begin{array}{l}306.22 \\
(13.15 \%)\end{array}$ & $-7.96 \%$ \\
\hline Agricultural & $213.39(9.16 \%)$ & $284.25(12.21 \%)$ & $3.04 \%$ & $\begin{array}{l}915.72 \\
(39.33 \%)\end{array}$ & $27.12 \%$ \\
\hline Barren & $749.53(32.19 \%)$ & $\begin{array}{l}1331.91 \\
(57.20 \%)\end{array}$ & $25.01 \%$ & $\begin{array}{l}791.05 \\
(33.97 \%)\end{array}$ & $-23.23 \%$ \\
\hline Built-up & $110.68(4.75 \%)$ & $225.47(9.68 \%)$ & $4.93 \%$ & $\begin{array}{l}301.82 \\
(12.96 \%)\end{array}$ & $3.28 \%$ \\
\hline Water & $2.37(0.10 \%)$ & $1.33(0.06 \%)$ & $-0.04 \%$ & $13.52(0.58 \%)$ & $0.52 \%$ \\
\hline Total & 2328.33 & 2328.33 & & 2328.33 & \\
\hline
\end{tabular}

Table 4: Change Matrix summary 2020-2030, 2030-2040, and 2040-2050 


\begin{tabular}{|c|c|c|c|c|c|c|c|}
\hline \multicolumn{8}{|c|}{ Prediction based on 2000-2010 LULC data } \\
\hline \multirow[t]{2}{*}{ Classes } & \multirow{2}{*}{$\begin{array}{l}\text { Year } 2020 \\
\text { Area in } \\
\mathrm{Km}^{2}\end{array}$} & \multirow{2}{*}{$\begin{array}{l}\text { Year } 2030 \\
\text { Area in } \\
\mathrm{Km}^{2}\end{array}$} & \multirow{2}{*}{$\begin{array}{l}2020-2030 \\
\text { Change } \\
(\%)\end{array}$} & \multirow{2}{*}{$\begin{array}{l}\text { Year } \\
2040 \\
\\
\text { Area in } \\
\mathrm{Km}^{2}\end{array}$} & \multirow{2}{*}{$\begin{array}{l}2030- \\
2040 \\
\text { Change } \\
(\%)\end{array}$} & \multirow{2}{*}{$\begin{array}{l}\text { Year } \\
2050 \\
\\
\text { Area in } \\
\mathrm{Km}^{2}\end{array}$} & \multirow{2}{*}{$\begin{array}{l}2040- \\
2050 \\
\text { Change } \\
(\%)\end{array}$} \\
\hline & & & & & & & \\
\hline Vegetation & 453.28 & 433.50 & -19.79 & 416.86 & -16.64 & 402.80 & -14.06 \\
\hline Agricultural & 279.13 & 266.51 & -12.62 & 254.84 & -11.67 & 244.86 & -9.98 \\
\hline Barren & 1259.51 & 1199.94 & -59.57 & 1151.15 & -48.79 & 1110.86 & -40.29 \\
\hline Built-up & 335.25 & 427329 & 92.04 & 504.42 & 77.13 & 568.76 & 64.34 \\
\hline Water & 1.16 & 1.09 & -0.07 & 1.06 & -0.03 & 1.05 & -0.01 \\
\hline Total & 2328.33 & 2328.33 & 0.00 & 2328.33 & 0.00 & 2328.33 & 0.00 \\
\hline \multicolumn{8}{|c|}{ Prediction based on 2010-2020 LULC data } \\
\hline \multicolumn{8}{|l|}{ Classes } \\
\hline Vegetation & 306.22 & 296.69 & -9.52 & 285.09 & -11.60 & 275.64 & -9.45 \\
\hline Agricultural & 915.72 & 878.71 & -37.08 & 846.40 & -32.31 & 820.31 & -26.09 \\
\hline Barren & 791.05 & 735.82 & -55.23 & 706.67 & -29.15 & 688.10 & -18.57 \\
\hline Built-up & 301.82 & 404.24 & 102.42 & 477.81 & 73.56 & 532.27 & 54.47 \\
\hline Water & 13.52 & 12.87 & -0.65 & 12.36 & -0.51 & 12.01 & -0.36 \\
\hline Total & 2328.33 & 2328.33 & 0.00 & 2328.33 & 0.00 & 2328.33 & 0.00 \\
\hline
\end{tabular}

\section{Figures}



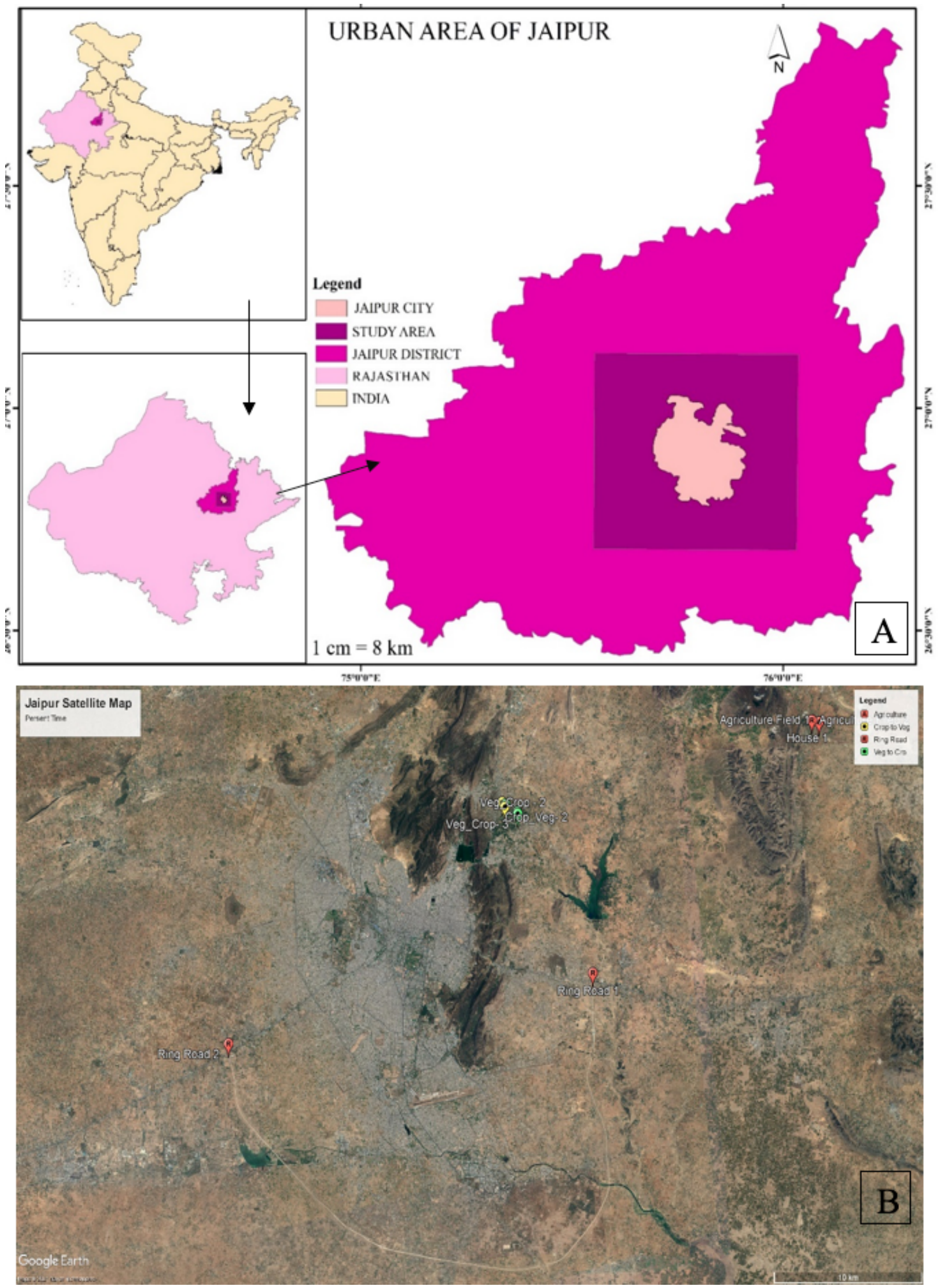

Figure 1

A) Locational map of the study area and B) Satellite Image of the present time 

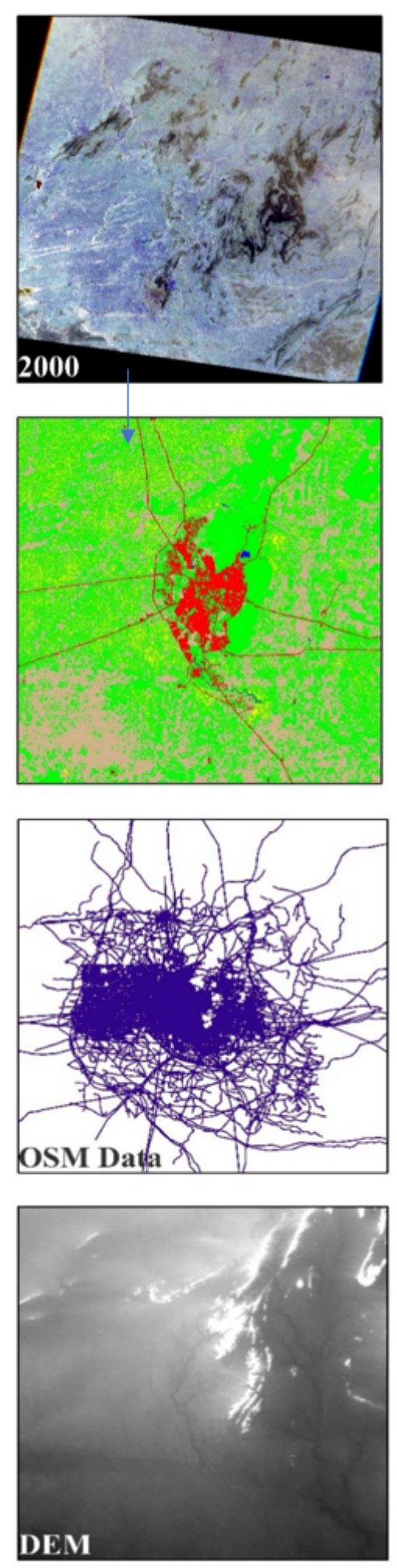
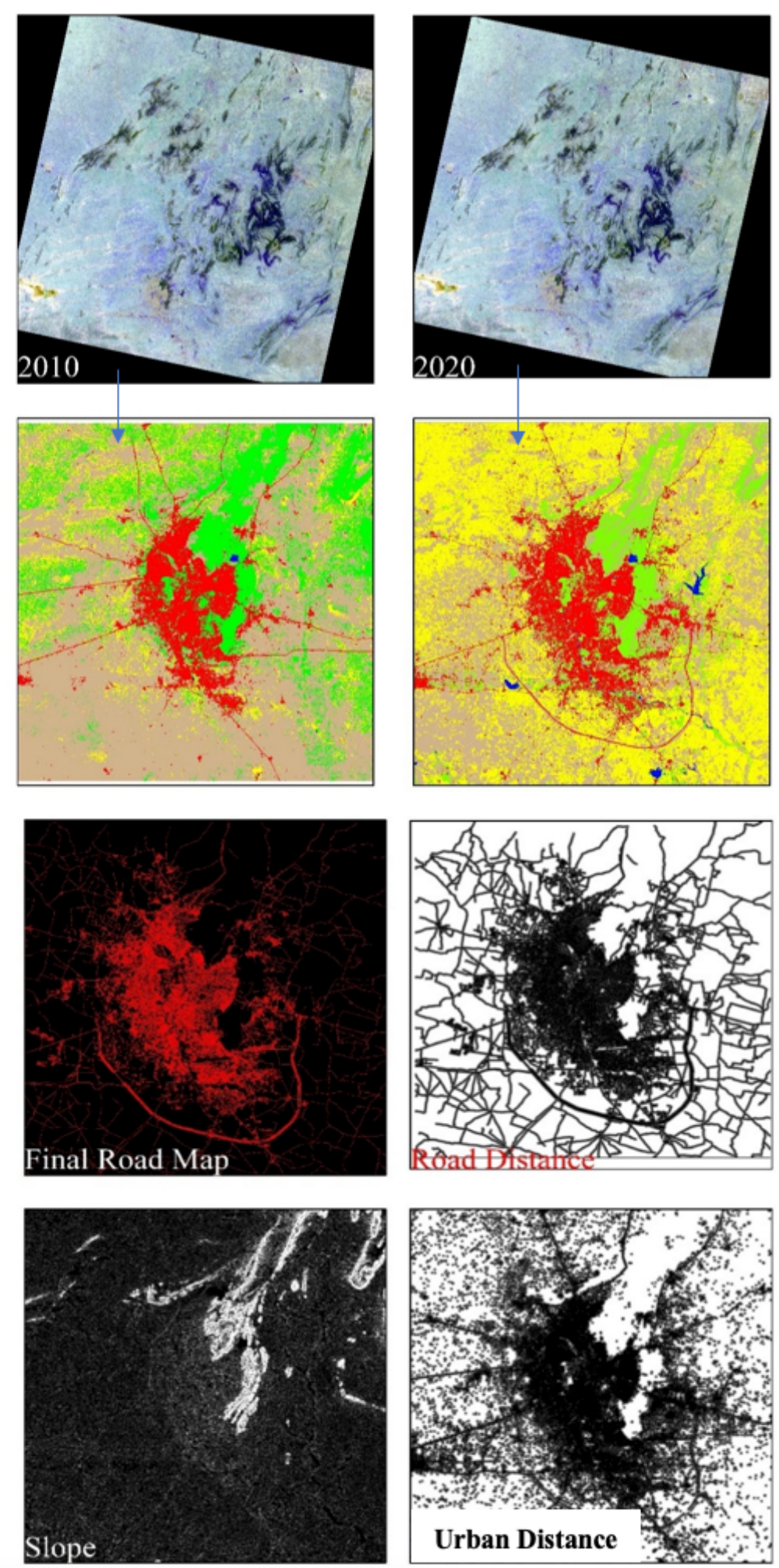
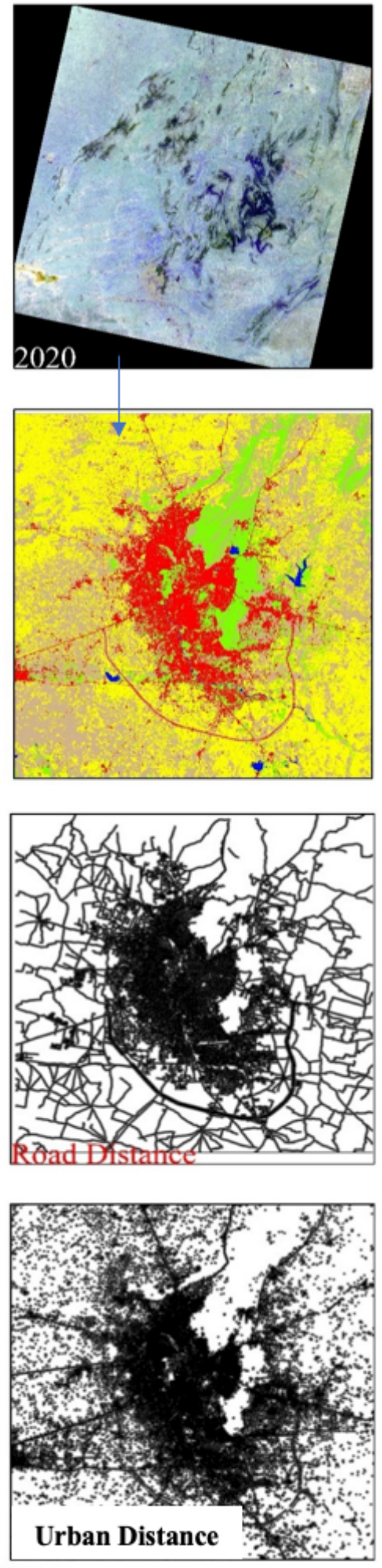

Figure 2

Raw data used in the analysis 


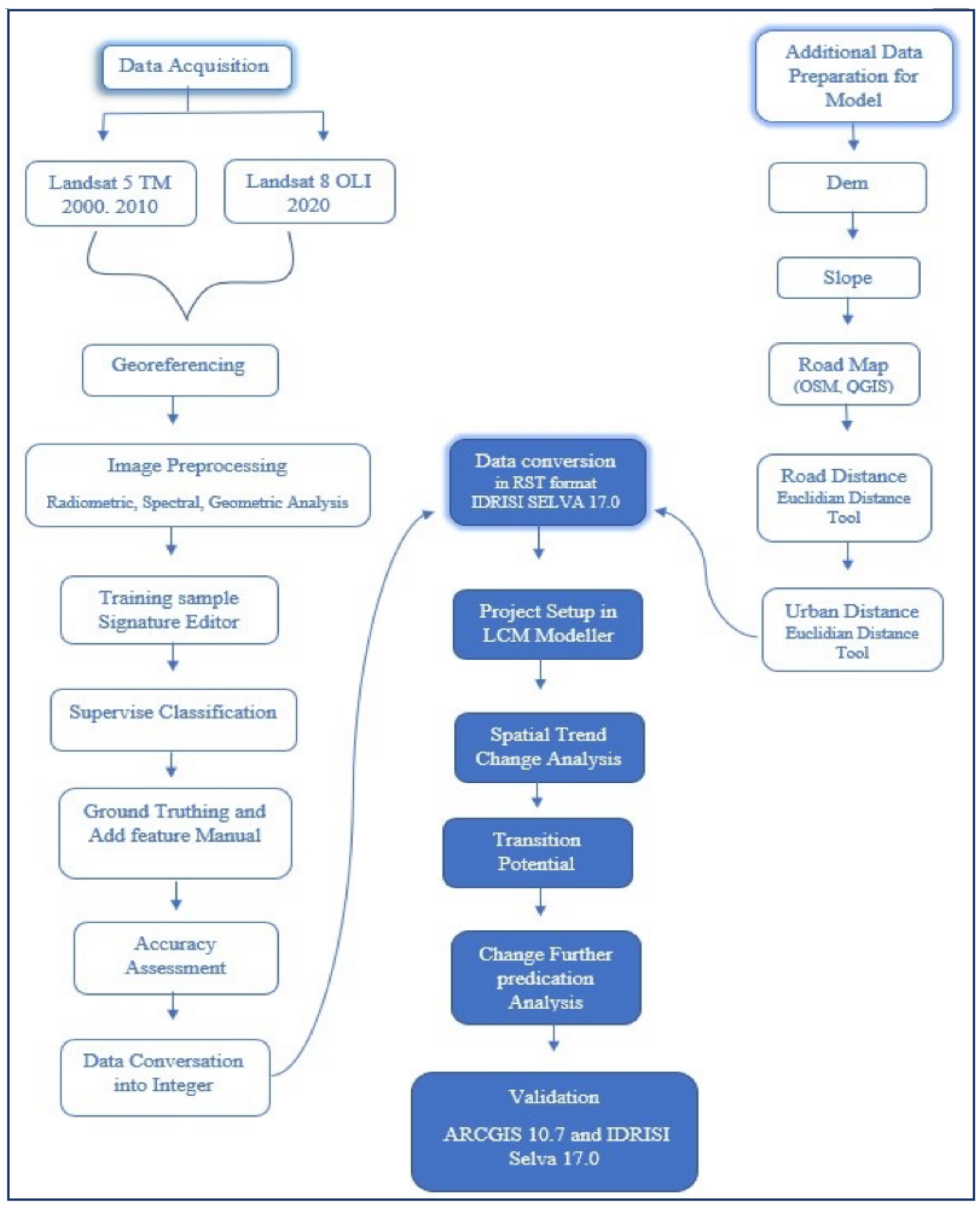

\section{Figure 3}

Flow chart of the methodology adopted in this study. 

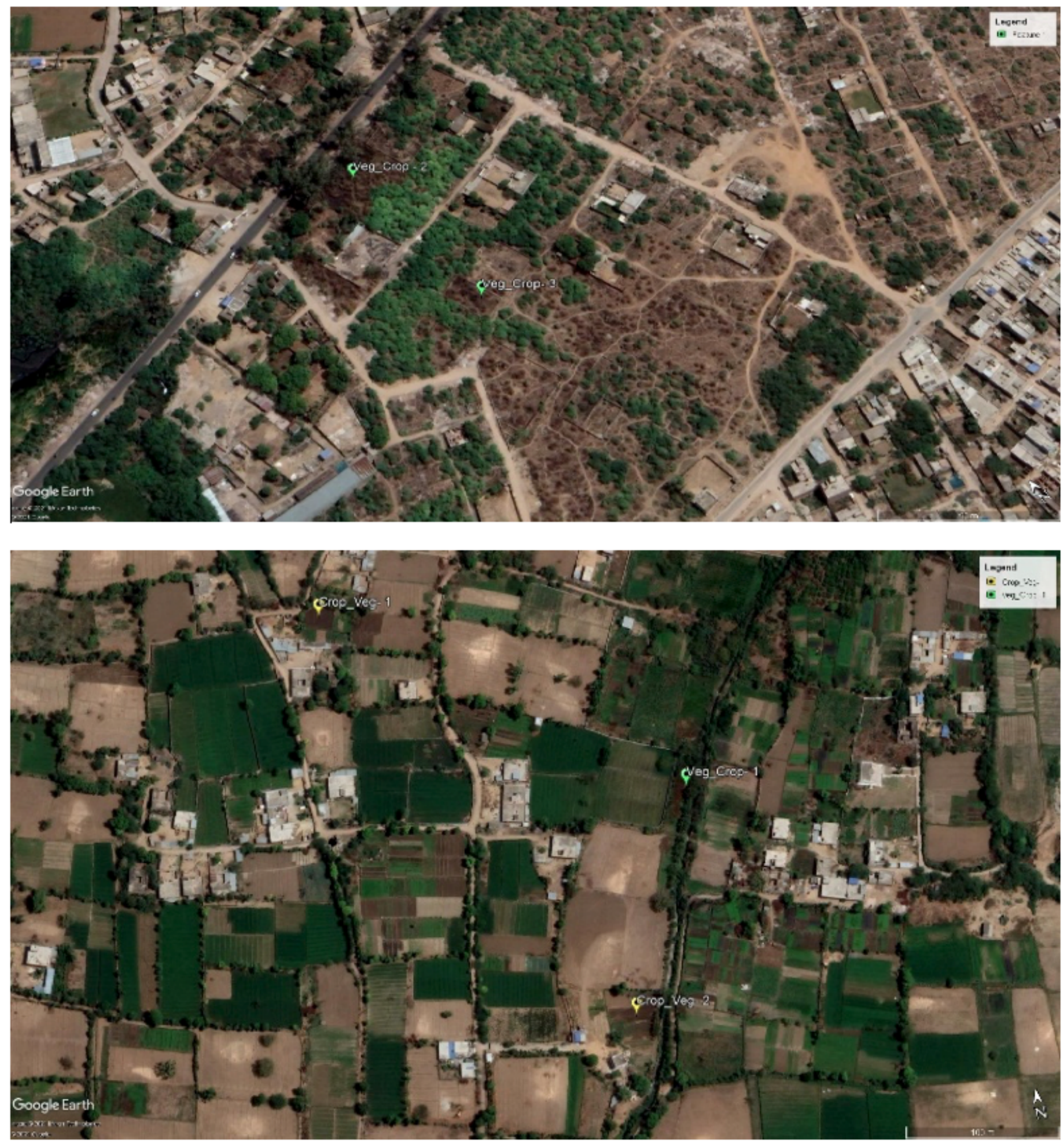

\section{Figure 4}

Vegetation and agricultural land reflecting the energy in the same spectrum leading to pixels mixing. 

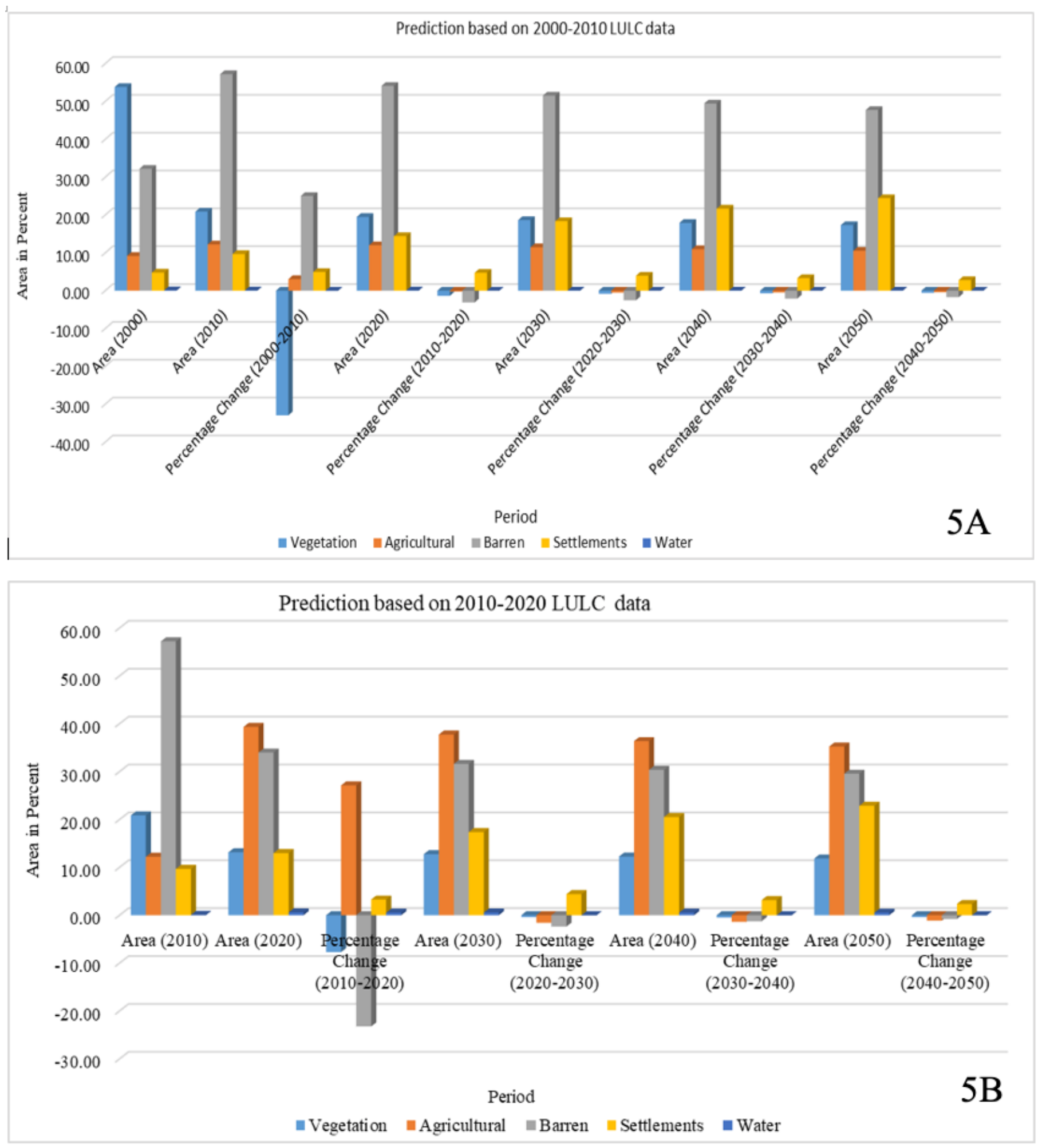

\section{Figure 5}

Urban Growth prediction for the years 2020, 2030, and 2050 based on (5A) 2000-2010 LULC and (5B) 2010-2020 LULC. 

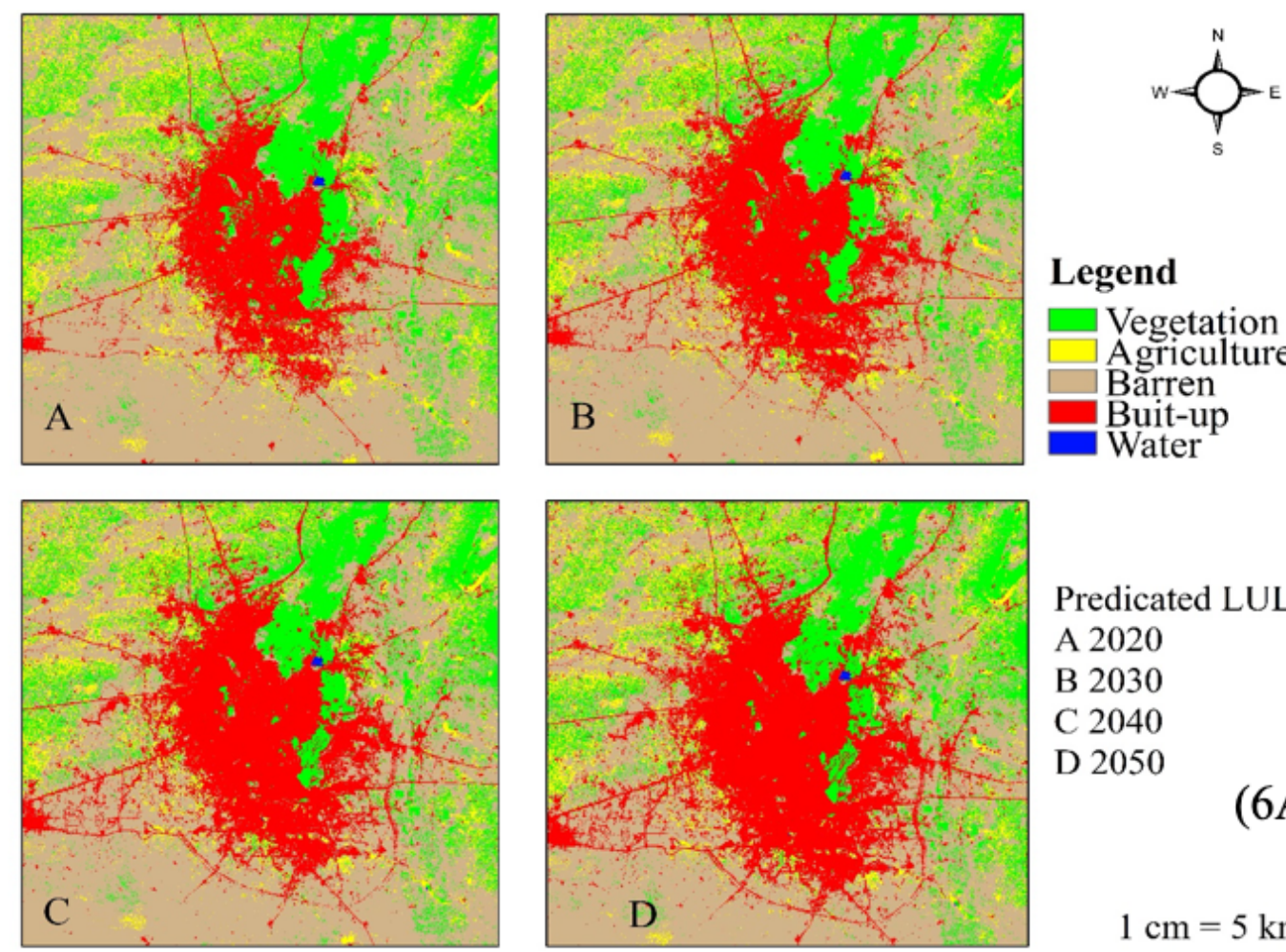

Legend
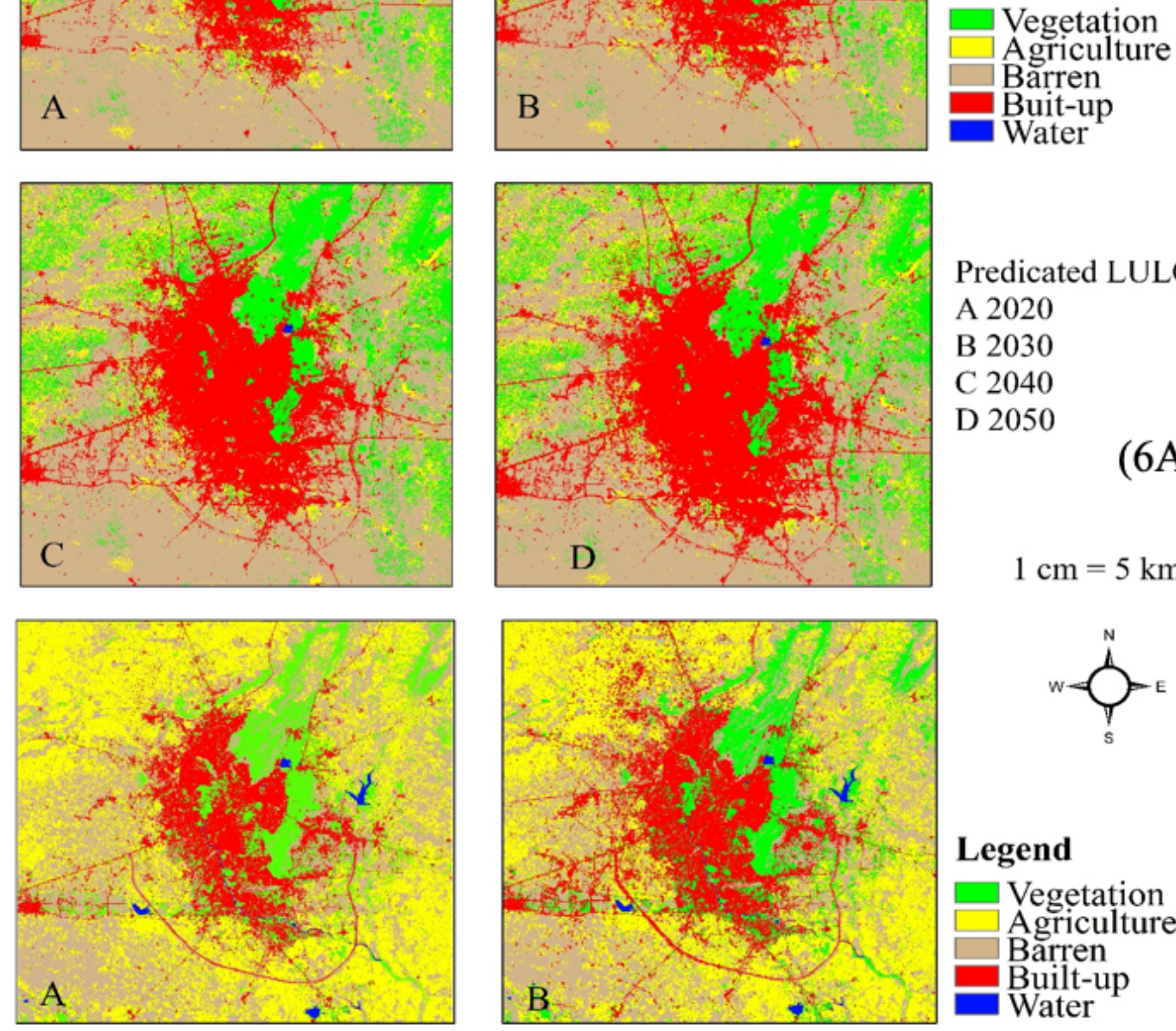

Predicated LULC

A 2020

B 2030

C 2040

D 2050

(6A)

$1 \mathrm{~cm}=5 \mathrm{~km}$

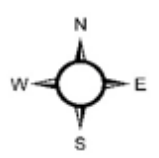

\section{Legend}

\begin{tabular}{l} 
Vegetation \\
Agriculture \\
Barren \\
Built-up \\
Water \\
\hline
\end{tabular}
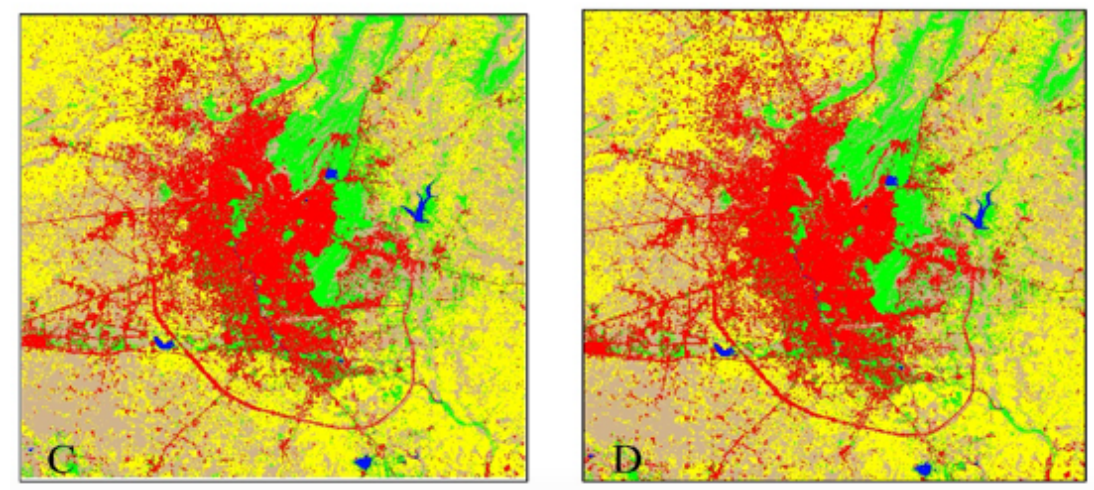

Predicated LULC
A 2020
B 2030
C 2040
D 2050

(6B)

$1 \mathrm{~cm}=5 \mathrm{~km}$

Figure 6

Urban Growth prediction for the years 2020, 2030, 2040, and 2050 based on (6A) 2000-2010 LULC maps and (6B) 2010-2020 LULC maps 


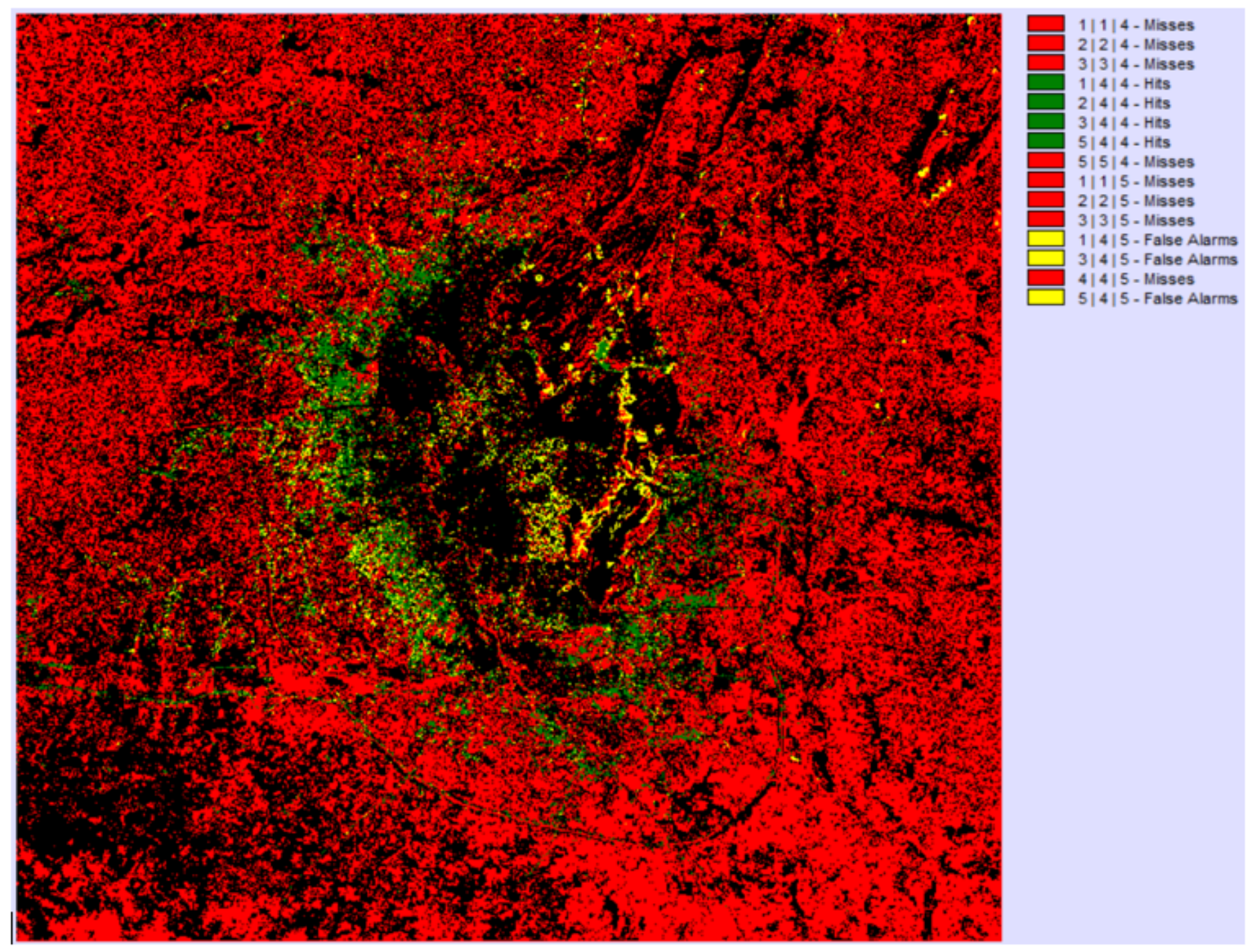

Figure 7

Validation of predicated 2020 from LULC 2010 data by Idrisi Sleva 17.0 


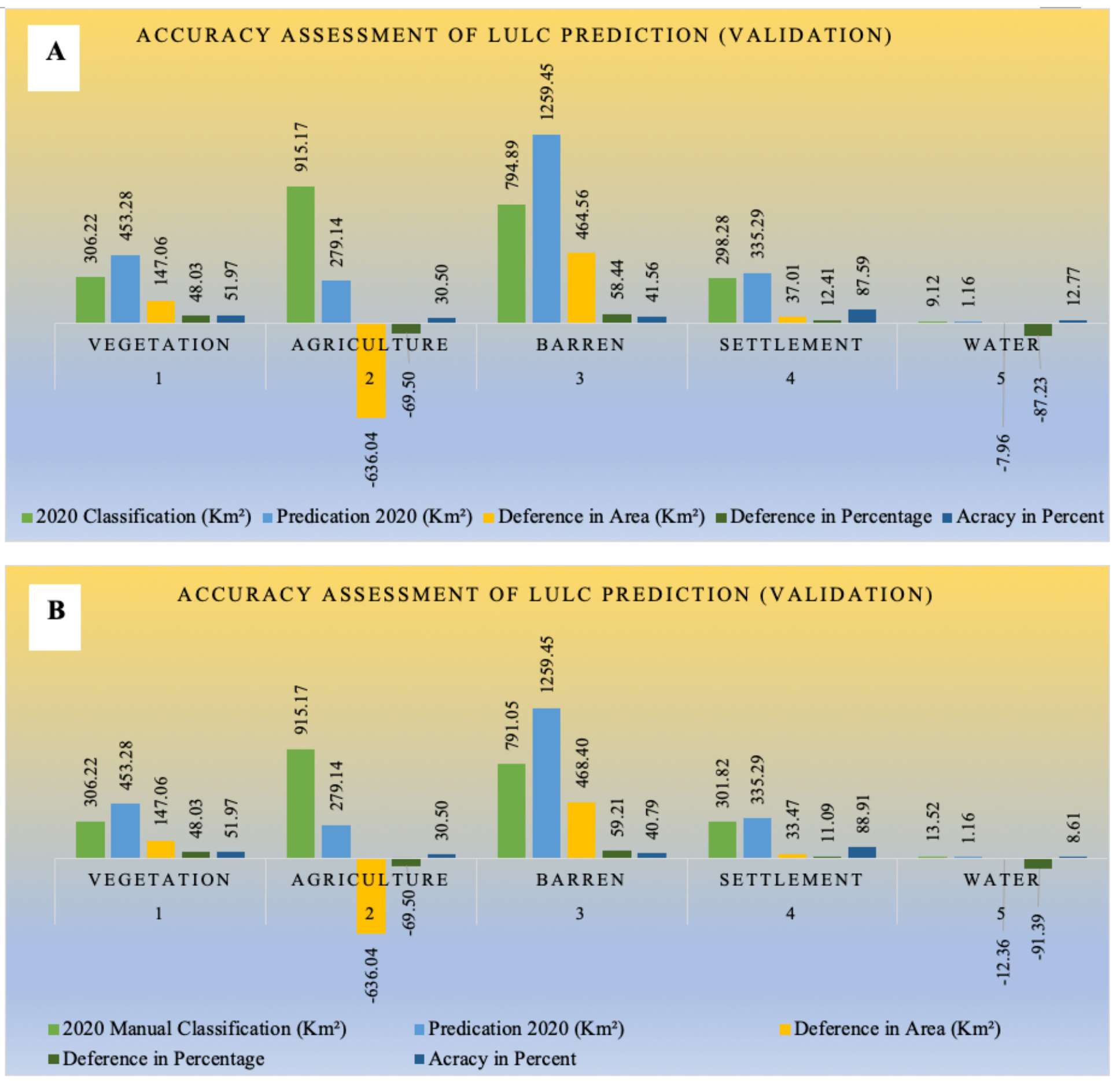

\section{Figure 8}

Accuracy assessment of predicated 2020 LULC (A) Validation with 2020 LULC (A) Validation with 2020 LULC integrated with road network 


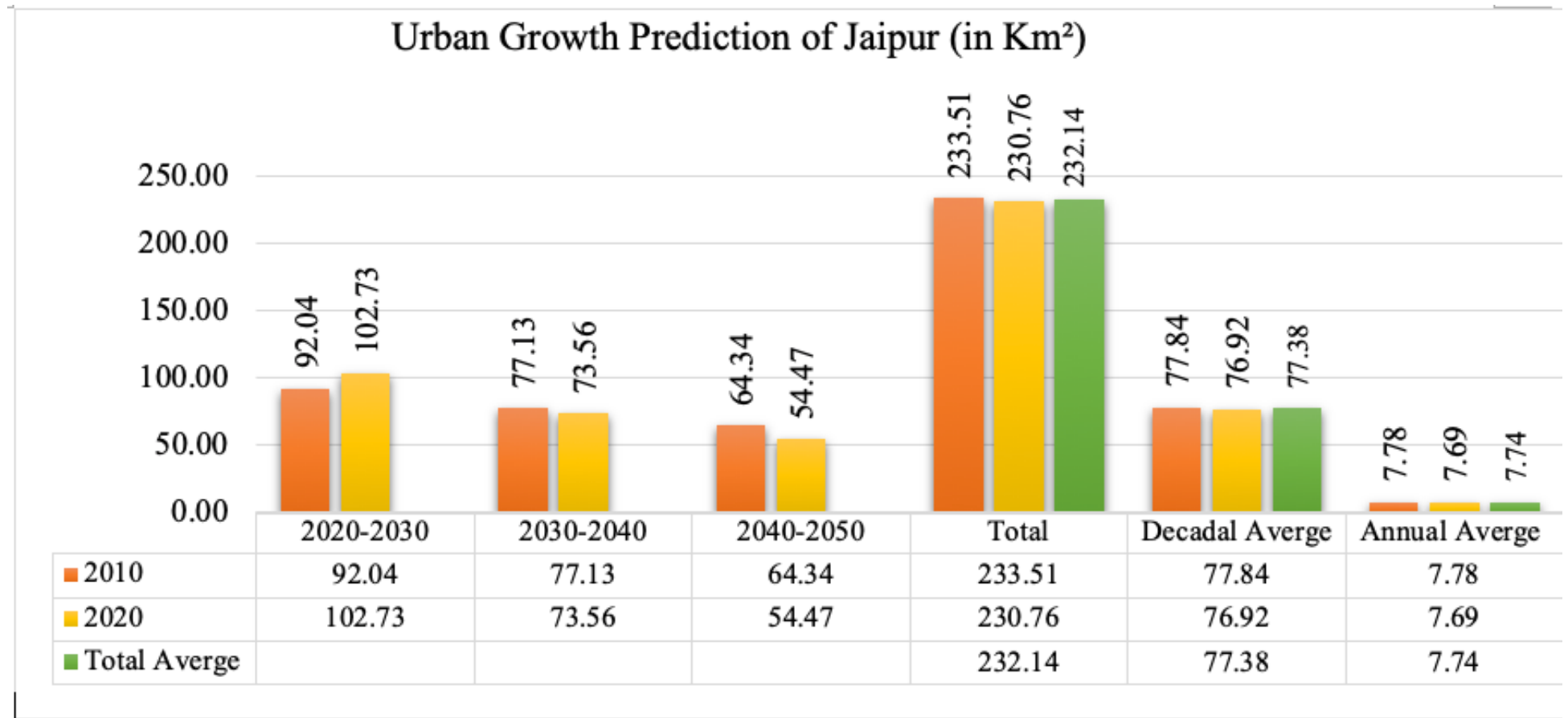

Figure 9

Comparision of urban growth prediction of Jaipur based on 2000-2010 and 2010-2020 LULC data 


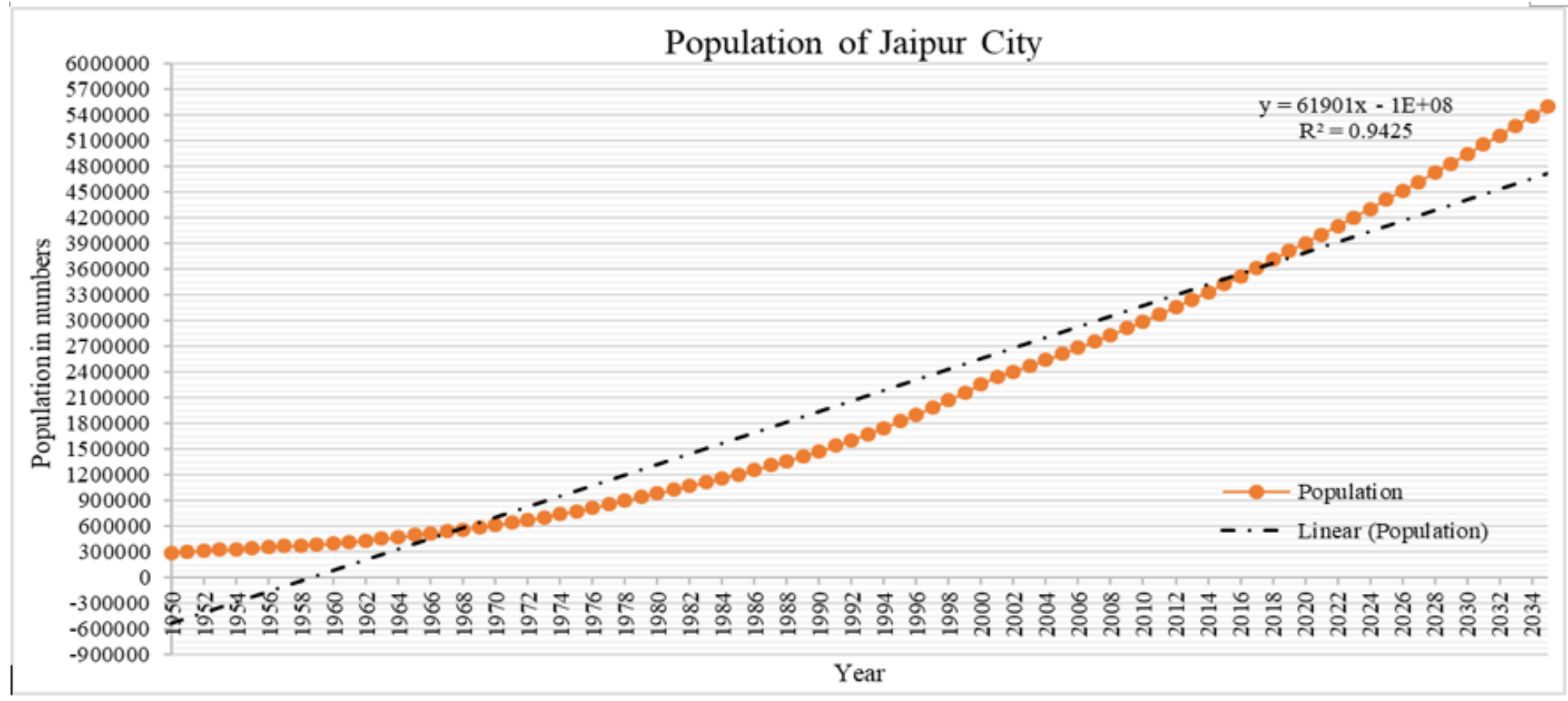

Figure. $10 \mathrm{a}$

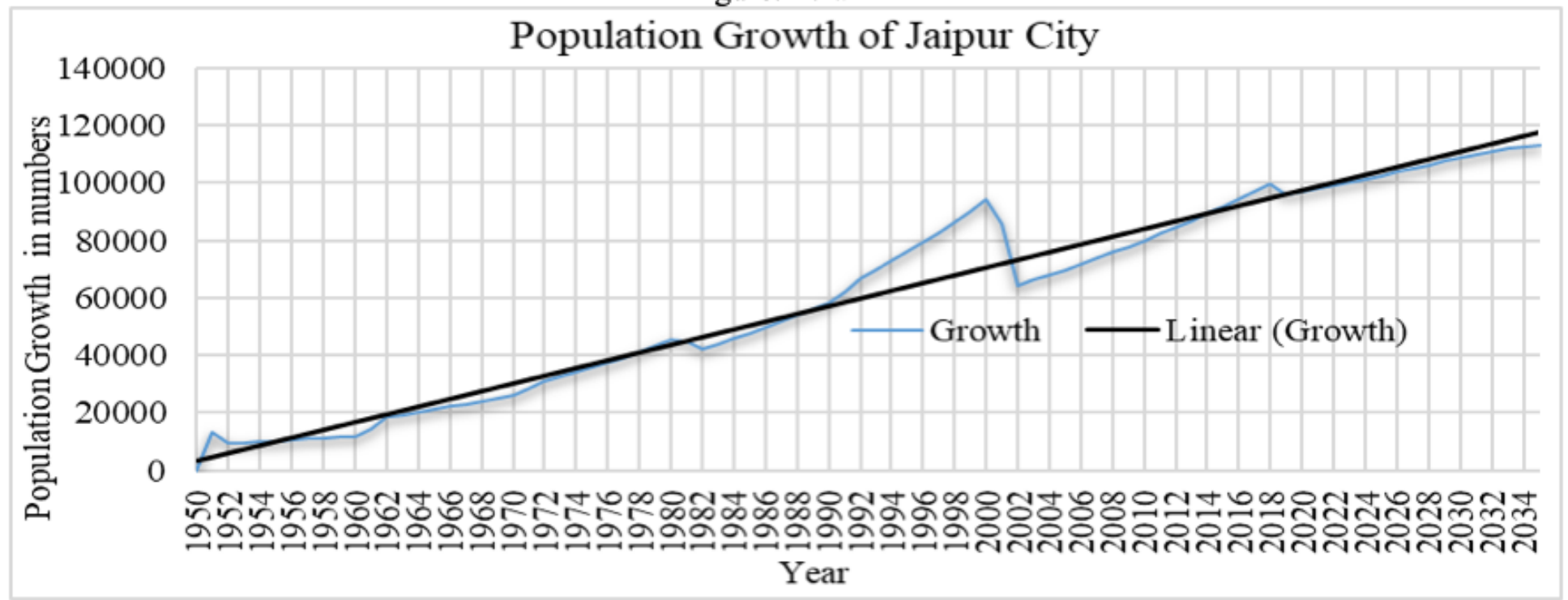

Figure. $10 \mathrm{~b}$

Figure 10

Population rise in Jaipur city a) Population in absolute numbers, b) Population growth in numbers 


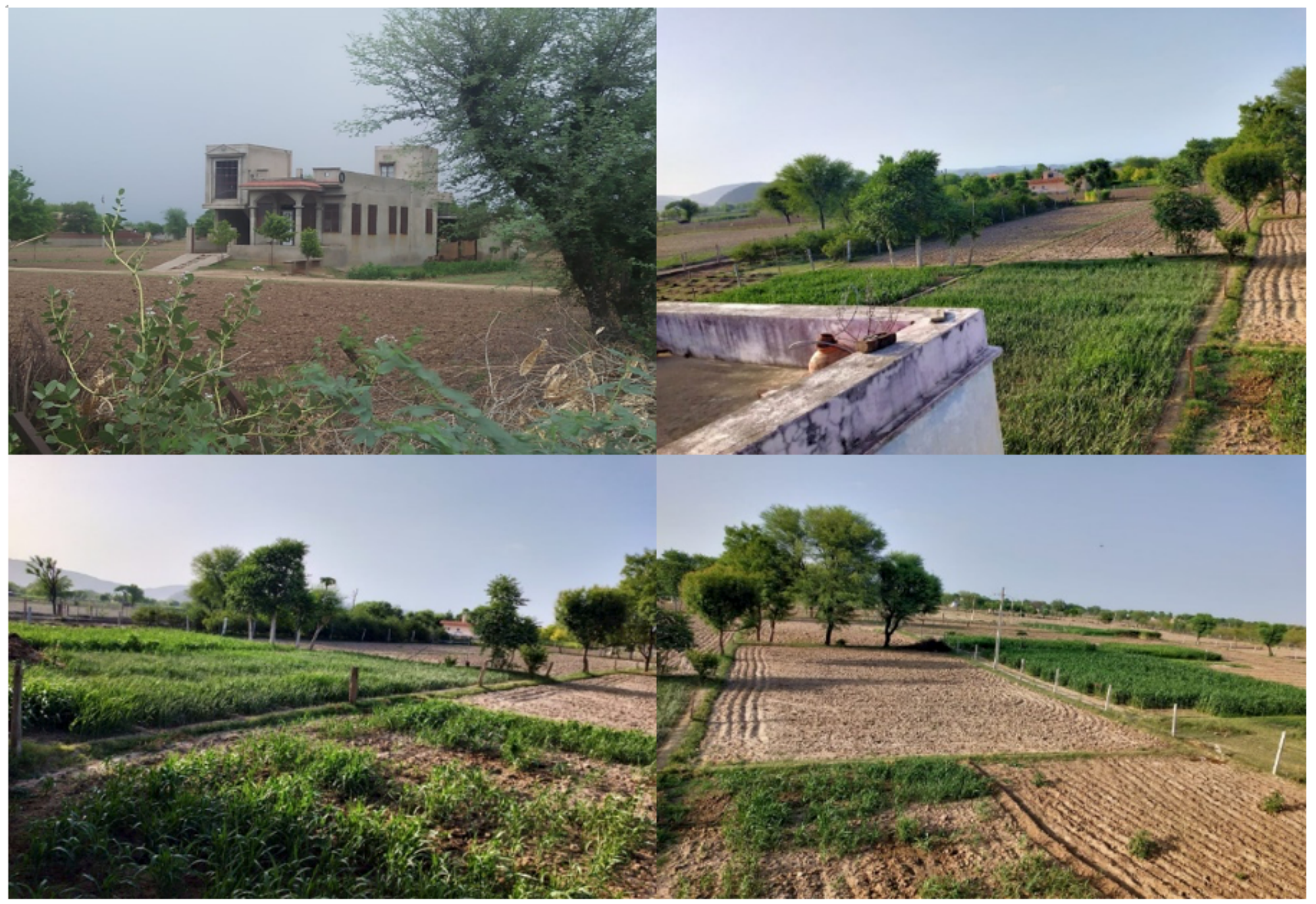

\section{Figure 11}

Conversion of larger farmlands into smaller units due to human settlement 

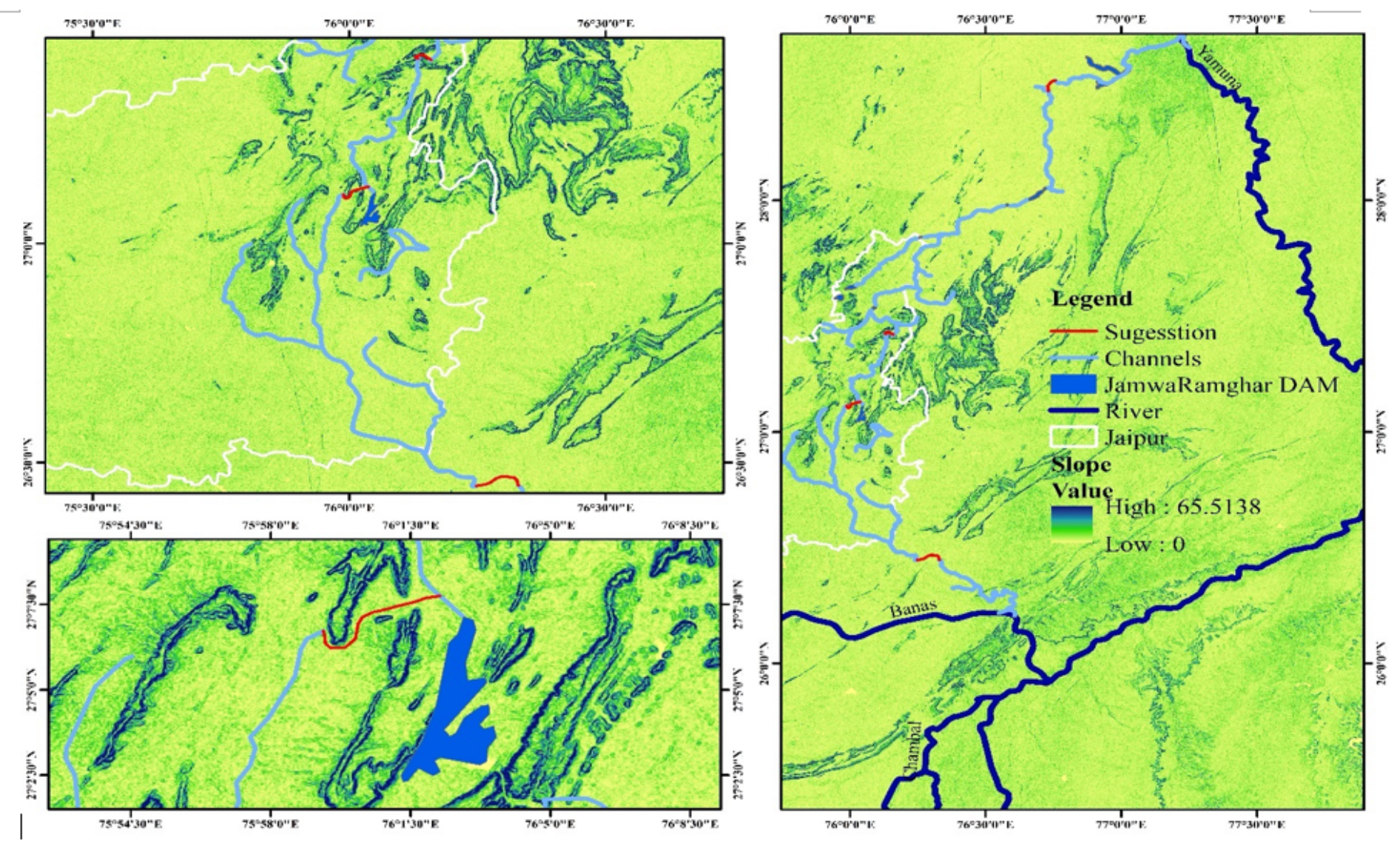

Figure 12

Proposal for water resource allocation 